NASA/TM-2006-214228

AIAA-2005-4271

\title{
NASA's 2004 In-Space Propulsion Refocus Studies for New Frontiers Class Missions
}

Kevin E. Witzberger and David Manzella

Glenn Research Center, Cleveland, Ohio

David Oh

Jet Propulsion Laboratory, Pasadena, California

Mike Cupples

Science Applications International Corporation, Huntsville, Alabama 


\section{NASA STI Program . . . in Profile}

Since its founding, NASA has been dedicated to the advancement of aeronautics and space science. The NASA Scientific and Technical Information (STI) program plays a key part in helping NASA maintain this important role.

The NASA STI Program operates under the auspices of the Agency Chief Information Officer. It collects, organizes, provides for archiving, and disseminates NASA's STI. The NASA STI program provides access to the NASA Aeronautics and Space Database and its public interface, the NASA Technical Reports Server, thus providing one of the largest collections of aeronautical and space science STI in the world. Results are published in both non-NASA channels and by NASA in the NASA STI Report Series, which includes the following report types:

- TECHNICAL PUBLICATION. Reports of completed research or a major significant phase of research that present the results of NASA programs and include extensive data or theoretical analysis. Includes compilations of significant scientific and technical data and information deemed to be of continuing reference value. NASA counterpart of peer-reviewed formal professional papers but has less stringent limitations on manuscript length and extent of graphic presentations.

- TECHNICAL MEMORANDUM. Scientific and technical findings that are preliminary or of specialized interest, e.g., quick release reports, working papers, and bibliographies that contain minimal annotation. Does not contain extensive analysis.

- CONTRACTOR REPORT. Scientific and technical findings by NASA-sponsored contractors and grantees.
- CONFERENCE PUBLICATION. Collected papers from scientific and technical conferences, symposia, seminars, or other meetings sponsored or cosponsored by NASA.

- SPECIAL PUBLICATION. Scientific, technical, or historical information from NASA programs, projects, and missions, often concerned with subjects having substantial public interest.

- TECHNICAL TRANSLATION. Englishlanguage translations of foreign scientific and technical material pertinent to NASA's mission.

Specialized services also include creating custom thesauri, building customized databases, organizing and publishing research results.

For more information about the NASA STI program, see the following:

- Access the NASA STI program home page at http://www.sti.nasa.gov

- E-mail your question via the Internet to help@sti.nasa.gov

- Fax your question to the NASA STI Help Desk at 301-621-0134

- Telephone the NASA STI Help Desk at 301-621-0390

- Write to:

NASA STI Help Desk

NASA Center for AeroSpace Information 7121 Standard Drive Hanover, MD 21076-1320 
NASA/TM-2006-214228

AIAA-2005-4271

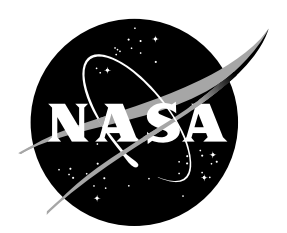

\section{NASA's 2004 In-Space Propulsion Refocus Studies for New Frontiers Class Missions}

Kevin E. Witzberger and David Manzella

Glenn Research Center, Cleveland, Ohio

David Oh

Jet Propulsion Laboratory, Pasadena, California

Mike Cupples

Science Applications International Corporation, Huntsville, Alabama

Prepared for the

41st Joint Propulsion Conference and Exhibit cosponsored by AIAA, ASME, SAE, and ASEE

Tucson, Arizona, July 10-13, 2005

National Aeronautics and

Space Administration

Glenn Research Center

Cleveland, Ohio 44135 


\section{Acknowledgments}

A portion of the research described in this paper was carried out at the Jet Propulsion Laboratory, California Institute of Technology, under a contract with the National Aeronautics and Space Administration. The rest of the research was carried out at the Science Applications International Corporation, Huntsville, Alabama, and NASA Glenn Research Center, Cleveland,

Ohio. The authors would like to acknowledge Gene Bonfiglio (JPL) for mission analysis work related to the Titan Orbiter/

Lander mission as well as members of JPL's advanced projects development team ("Team X") for their contributions to this paper. This work is sponsored by NASA and was managed by Randy Baggett (MSFC), project manager of the Solar Electric Propulsion Technology area of the In-Space Propulsion program, and by Melody Hermann (MSFC), project manager of the Systems Analysis area of the In-Space Propulsion program.

This report contains preliminary findings, subject to revision as analysis proceeds.

Level of Review: This material has been technically reviewed by technical management.

Available from

NASA Center for Aerospace Information 7121 Standard Drive

Hanover, MD 21076-1320
National Technical Information Service 5285 Port Royal Road Springfield, VA 22161

Available electronically at http://gltrs.grc.nasa.gov 


\title{
NASA's 2004 In-Space Propulsion Refocus Studies for New Frontiers Class Missions
}

\author{
Kevin E. Witzberger and David Manzella \\ National Aeronautics and Space Administration \\ Glenn Research Center \\ Cleveland, Ohio 44135 \\ David Oh \\ National Aeronautics and Space Administration \\ Jet Propulsion Laboratory \\ Pasadena, California 91109 \\ Mike Cupples \\ Science Applications International Corporation \\ Huntsville, Alabama 35806
}

The New Frontiers (NF) program is designed to provide opportunities to fulfill the science objectives for top priority, medium class missions identified in the Decadal Solar System Exploration Survey. This paper assesses the applicability of the In-Space Propulsion's (ISP) Solar Electric Propulsion (SEP) technologies for representative NF class missions that include a Jupiter Polar Orbiter with Probes (JPOP), Comet Surface Sample Return (CSSR), and two different Titan missions. The SEP technologies evaluated include the 7-kW, 4,100-second NASA's Evolutionary Xenon Thruster (NEXT), the 3-kW, 2,700-second Hall thruster, and two different NASA Solar Electric Propulsion Technology Readiness (NSTAR) thrusters that are variants of the Deep Space 1 (DS1) thruster. One type of NSTAR, a $2.6-\mathrm{kW}, 3,100$-second thruster, will be the primary propulsion system for the DAWN mission that is scheduled to launch in 2006; the other is an "enhanced", higher power variant $(3.8-\mathrm{kW}, 4,100$-second) and is so-called because it uses NEXT system components such as the NEXT power processing unit (PPU). The results show that SEP is applicable for the CSSR mission and a Titan Lander mission. In addition, NEXT has improved its applicability for these types of missions by modifying its thruster performance relative to its performance at the beginning of this study.

\section{Nomenclature}

$\begin{array}{ll}A U & \text { Astronomical Unit } \\ B O L & \text { beginning-of-life } \\ C_{3} & \text { vis-viva energy, } \mathrm{km}^{2} / \mathrm{s}^{2} \\ \Delta V & \text { velocity change of spacecraft, } \mathrm{km} / \mathrm{s} \\ R_{J} & \text { radius of Jupiter } \\ R O M & \text { rough order of magnitude } \\ V_{\infty} & \text { spacecraft velocity at the sphere of influence with respect to the target planet, } \mathrm{km} / \mathrm{s}\end{array}$




\section{Introduction}

$\mathrm{N}$ ew Frontier-class missions are medium-class space science exploration missions that are intended to substantially improve our understanding of important phenomena that includes, for example, how the nine planets formed and the existence (or non-existence) of life beyond Earth. Discovery and Flag Ship missions also have the same top-level objective, but with different cost-caps. The cost-cap for New Frontiers missions is $\sim \$ 750 \mathrm{M}$ in fiscal year (FY) 2004 dollars.

Candidate medium-class missions are prioritized in the Decadal Solar System Exploration Survey (DSSES) according to scientific merit, "opportunity" (i.e. budgetary, planetary phasing, etc), and technological readiness. ${ }^{1}$ This paper assesses electric thruster technologies that serve as the spacecraft's primary propulsion system. The DSSES lists about ten candidate medium-class missions for the 2003 - 2023 time frame. Assessing the performance of the ISP SEP technologies for each of these missions was far beyond the scope of this study. Instead, three representative medium-class missions that were expected to be within the New Frontiers cost-cap at the time this analysis was performed were chosen for mission analysis. Two of these missions, a Comet Surface Sample Return (CSSR) mission and the Jupiter Polar Orbiter with Probes (JPOP) mission, were listed as medium-class missions in the DSSES. The third, a mission to Titan, is a variant of the Titan Orbiter and Lander mission that was classified as a large-class (Flag Ship) mission in the DSSES.

Each mission utilizes a specific SEP technology as the spacecraft's primary propulsion system to provide the post-launch electric $\Delta \mathrm{V}$. Performance comparisons for each electric thruster are made to meet the first of the three main objectives of this Refocus Study:

(1) Determine the applicability of SEP systems to representative NF-class missions and consider thruster performance modifications that would increase applicability;

(2) Identify synergism of NEXT and NSTAR based systems which may lower recurring cost and/or improve performance;

(3) Identify other near-term NSTAR improvements.

The last two objectives of the Refocus Study are addressed in the Discovery-class portion of the Refocus Study; therefore, this paper only addresses the first main objective listed above. ${ }^{2}$ Cost analysis is performed only for the Titan mission to identify which concept (lander or orbiter) shows potential to fall within the NF mission cost-cap with the NEXT ion system serving as the primary propulsion system; it was the only SEP technology assessed for the Titan mission.

For the purpose of this study, a SEP technology is considered to be applicable for a particular mission if it can offer a "good" combination of performance, cost, and number of required thrusters (a maximum requirement of three total thrusters would classify the SEP technology as applicable assuming performance and cost are acceptable).

To really understand the efficacy of SEP for science mission applications, a comparison with all-chemical propulsion is desirable. In this study, the JPOP mission is the only one that has a direct, although somewhat limited, SEP performance comparison with all-chemical propulsion (Reference 11 has a more robust performance comparison). A recent study that leveraged off this one did capture performance and cost comparisons with chemical options for other potential NF-class missions (including the CSSR mission). ${ }^{3}$

A brief description of each SEP technology is presented in section II. Section III describes top-level modeling and assumptions that includes thruster modeling and propulsion system mass assumptions. Section IV discusses the mission analysis and results for each mission. Conclusions and findings of this study are presented in section V.

\section{SEP Technologies}

A very brief description of the ISP's SEP technologies considered in this study is given below along with reference for a more detailed description.

- NSTAR: $30 \mathrm{~cm}$ ion thruster subsystem, previously flown on Deep Space 1, representing the current state of the art in electric propulsion for deep space missions. ${ }^{4}$ 
- NASA's Evolutionary Xenon Thruster (NEXT): $\sim 7 \mathrm{~kW}$ ion thruster subsystem currently under development by a joint government-industry-academia team including members of NASA Glenn Research Center (GRC), the Jet Propulsion Laboratory (JPL), Aerojet-Redmond, L3 Communication Electron Technologies Inc. (L-3 ETI), the University of Michigan, Colorado State University (CSU), and the Applied Physics Laboratory (APL). ${ }^{5}$

- Enhanced NSTAR: a proposed improvement to the existing NSTAR subsystem using a combination of carbon based ion optics (CBIO) currently under development by a team including members of JPL, L-3 ETI, and CSU, and a high power processing unit developed through the NEXT program. ${ }^{6}$

- 3-kW Hall: A SEP Hall thruster based on the High Voltage Hall Accelerator (HIVHAC) development project including members of GRC, Aerojet, JPL, and the University of Michigan. The objective of this project initiated in 2004 was to adapt Hall thruster technology for NASA interplanetary mission applications. This has required a Hall thruster with increased specific impulse and the ability to operate efficiently over a range of input powers. The thruster under development was designed to operate at power levels ranging from $300-2800$ Watts while providing specific impulses ranging from 1500 to 2700 seconds. This power level was chosen to optimize the applicability of this technology for NASA Discovery class mission applications. Discovery class missions were targeted due to the potential recurring cost benefit of Hall thruster systems relative to other electric propulsion systems. Improvements in thruster lifetime are also being addressed through the HIVHAC project, as some potential interplanetary missions require thruster throughputs in excess in of those demonstrated by Hall thrusters for Earth orbital applications. The remainder of the Hall thruster system utilized in these analyses was derivatives of existing Hall thruster system technology that is anticipated to be suitable for interplanetary applications with several modifications.

\section{Top-level Modeling and Assumptions}

\section{A. Thruster Modeling}

The thruster performance data (throttle tables) that are provided by the technologists are modeled with a polynomial curve fit for input into a low-thrust trajectory optimization tool. The form of the polynomial is given in Eq. (1), where P is the PPU input power in kilowatts and y represents either thrust or mass flow rate.

$$
y=a+b P+c P^{2}+d P^{3}+e P^{4}
$$

Table 1 provides the corresponding polynomial coefficients and Fig. 1 and 2 show the curve fits.

Table $14^{\text {th }}$ order polynomial curve fit coefficients

\begin{tabular}{|c|c|c|c|c|c|c|c|c|c|c|}
\hline \multirow{3}{*}{ Coefficient } & \multicolumn{2}{|c|}{ 3-kW Hall } & \multicolumn{2}{|c|}{ 2.6-kW NSTAR Q-Mod } & \multicolumn{2}{|c|}{ 3.8-kW Enhanced NSTAR } & \multicolumn{4}{|c|}{$7-\mathrm{kW}$ NEXT } \\
\hline & \multirow[b]{2}{*}{$\begin{array}{l}\text { Mass flow } \\
\text { rate, } \mathrm{kg} / \mathrm{s}\end{array}$} & \multirow[b]{2}{*}{ Thrust, N } & \multirow[b]{2}{*}{$\begin{array}{l}\text { Mass flow } \\
\text { rate, } \mathrm{kg} / \mathrm{s}\end{array}$} & \multirow[b]{2}{*}{ Thrust, N } & \multirow[b]{2}{*}{$\begin{array}{l}\text { Mass flow } \\
\text { rate, } \mathrm{kg} / \mathrm{s}\end{array}$} & \multirow[b]{2}{*}{ Thrust, N } & \multicolumn{2}{|c|}{ High Isp } & \multicolumn{2}{|c|}{ High Thrust } \\
\hline & & & & & & & $\begin{array}{l}\text { Mass flow } \\
\text { rate, } \mathrm{kg} / \mathrm{s}\end{array}$ & Thrust, N & $\begin{array}{l}\text { Mass flow } \\
\text { rate, } \mathrm{kg} / \mathrm{s}\end{array}$ & Thrust, N \\
\hline a & $4.972 \mathrm{E}-07$ & $3.079 \mathrm{E}-03$ & $2.506 \mathrm{E}-06$ & $2.634 \mathrm{E}-02$ & $3.594 \mathrm{E}-07$ & $-2.282 \mathrm{E}-03$ & $1.944 \mathrm{E}-06$ & $-8.954 \mathrm{E}-05$ & $3.131 \mathrm{E}-06$ & $1.680 \mathrm{E}-02$ \\
\hline b & $2.952 \mathrm{E}-06$ & $5.542 \mathrm{E}-02$ & $-5.357 \mathrm{E}-06$ & $-5.169 \mathrm{E}-02$ & $1.567 \mathrm{E}-06$ & $3.848 \mathrm{E}-02$ & $1.768 \mathrm{E}-07$ & $5.232 \mathrm{E}-02$ & $-2.621 \mathrm{E}-06$ & $1.188 \mathrm{E}-02$ \\
\hline c & $-1.166 \mathrm{E}-06$ & $-1.066 \mathrm{E}-02$ & $6.254 \mathrm{E}-06$ & $9.049 \mathrm{E}-02$ & $-5.941 \mathrm{E}-07$ & $8.267 \mathrm{E}-04$ & $-1.898 \mathrm{E}-07$ & $-1.402 E-02$ & $1.660 \mathrm{E}-06$ & $1.293 \mathrm{E}-02$ \\
\hline$d$ & $3.296 \mathrm{E}-07$ & $2.852 E-03$ & $-2.537 \mathrm{E}-06$ & $-3.672 E-02$ & $1.577 \mathrm{E}-07$ & $-1.555 \mathrm{E}-03$ & 7.637E-08 & $2.926 \mathrm{E}-03$ & $-2.832 E-07$ & $-2.234 \mathrm{E}-03$ \\
\hline e & $-3.766 \mathrm{E}-08$ & $-3.178 \mathrm{E}-04$ & $3.698 \mathrm{E}-07$ & $5.146 \mathrm{E}-03$ & $-1.647 \mathrm{E}-08$ & $2.340 \mathrm{E}-04$ & $-6.024 \mathrm{E}-09$ & $-1.889 \mathrm{E}-04$ & $1.531 \mathrm{E}-08$ & $1.102 \mathrm{E}-04$ \\
\hline
\end{tabular}




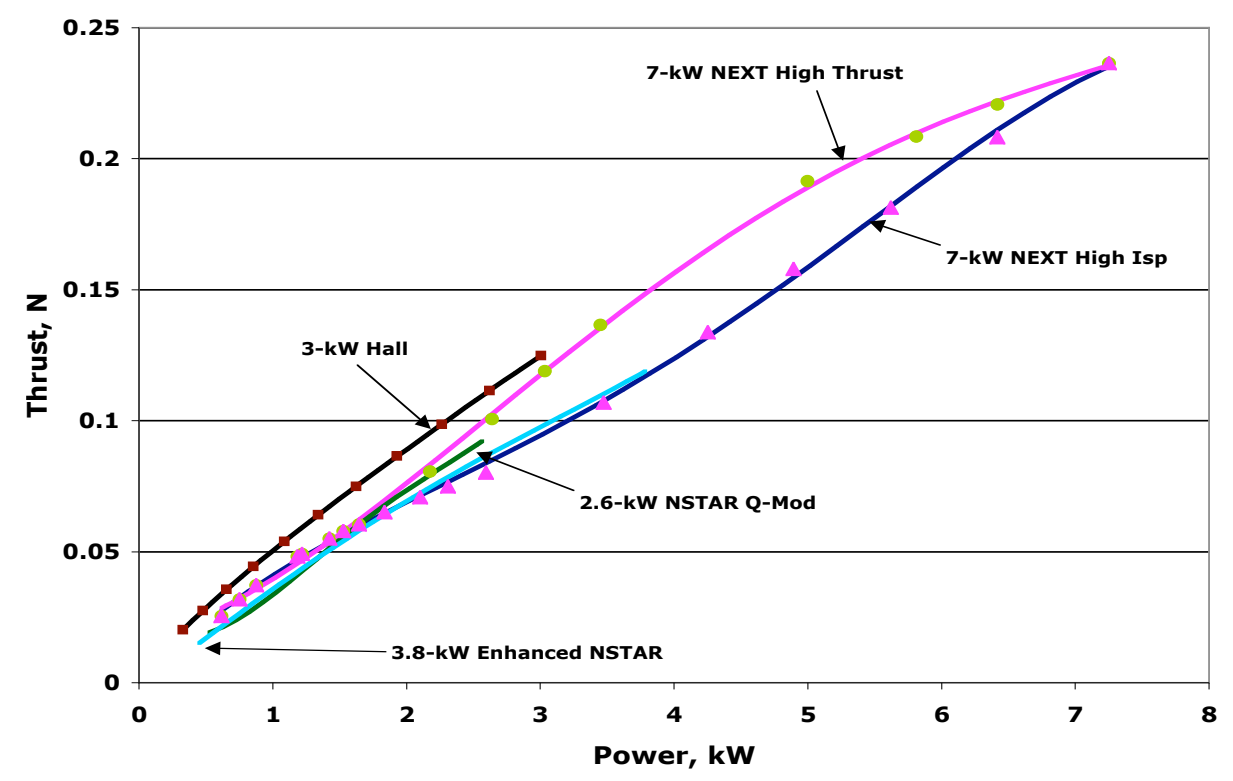

Figure 1. Thrust vs. power data and curve fits for each SEP technology.

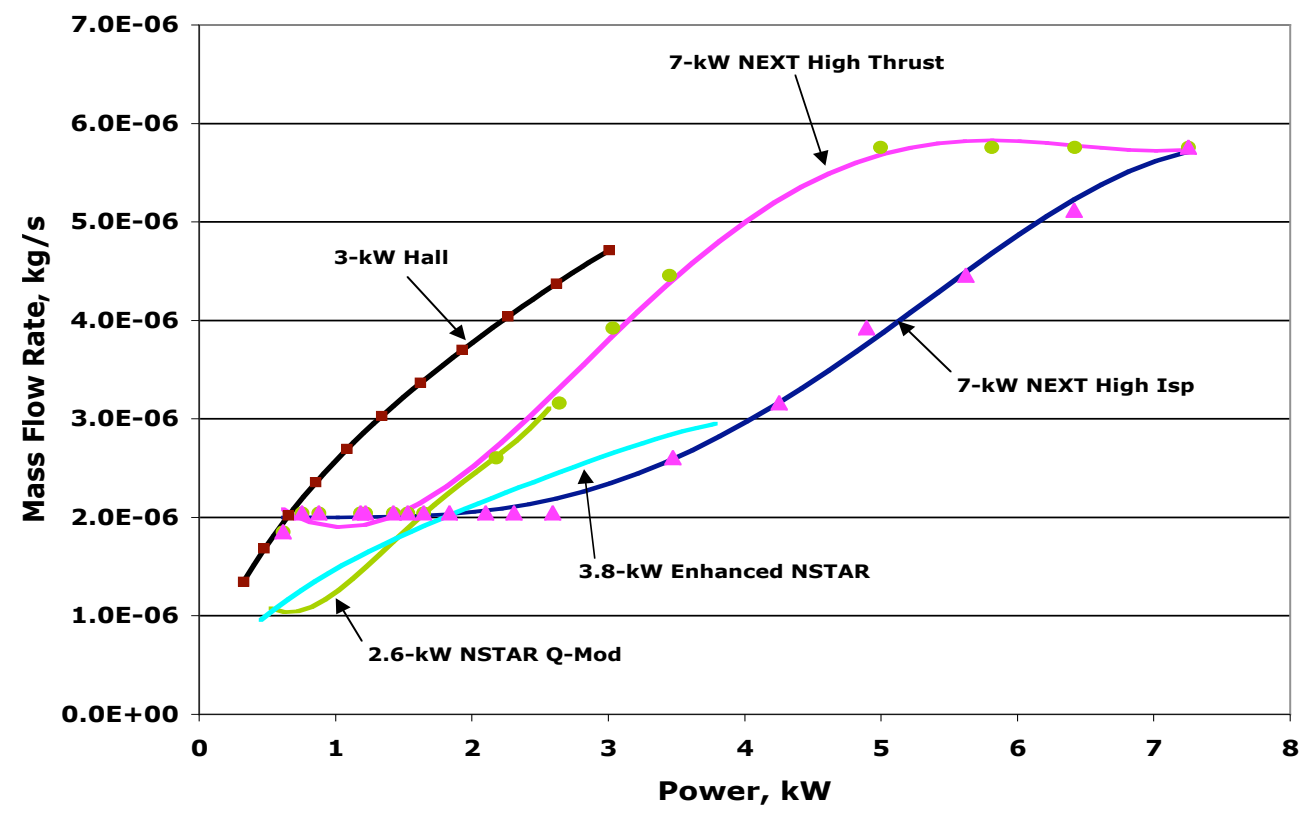

Figure 2. Mass flow rate vs. power data and curve fits for each SEP technology.

From these curve fits, each thruster's specific impulse $\left(I_{\mathrm{sp}}\right)$ and overall efficiency as a function of PPU input power are calculated and shown in Fig. 3 and 4. 


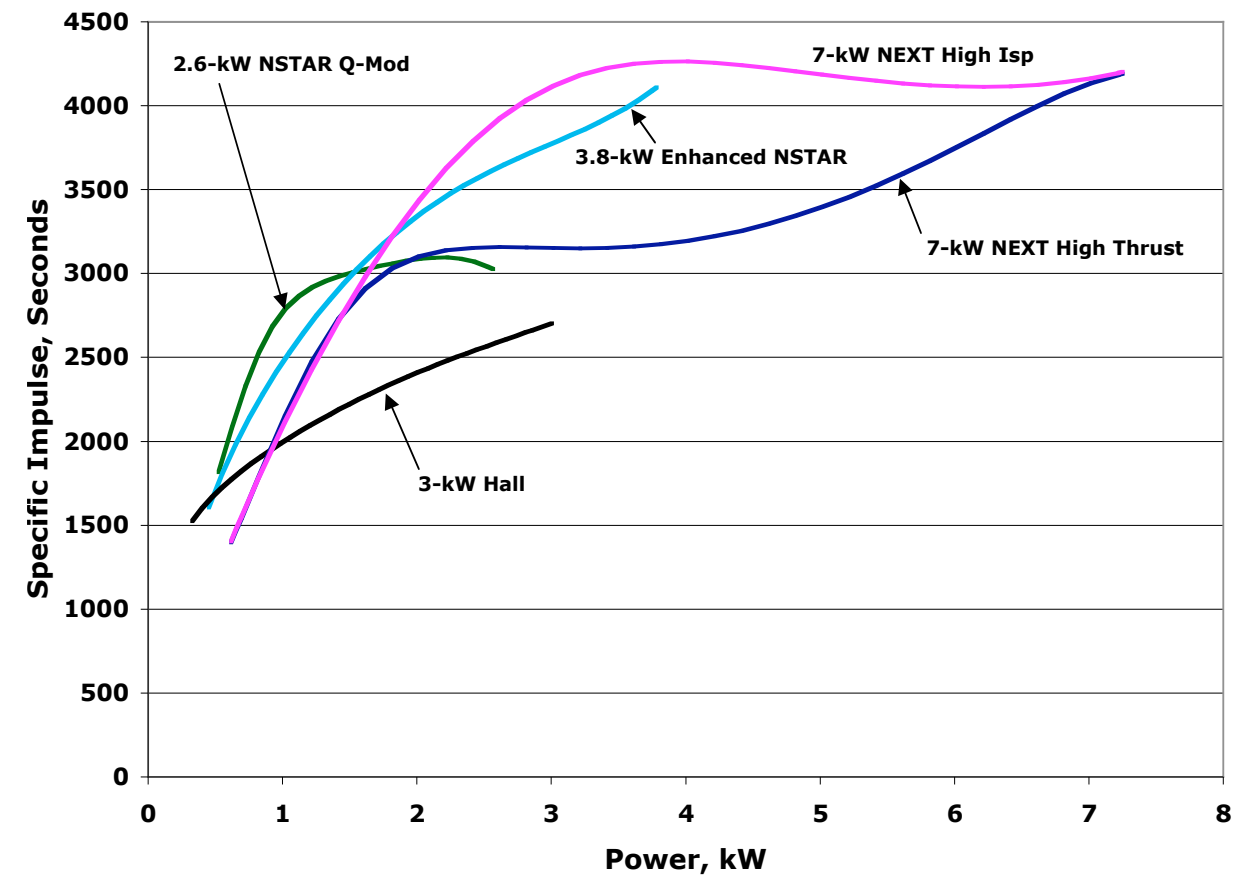

Figure 3. Specific impulse vs. power for each SEP technology.

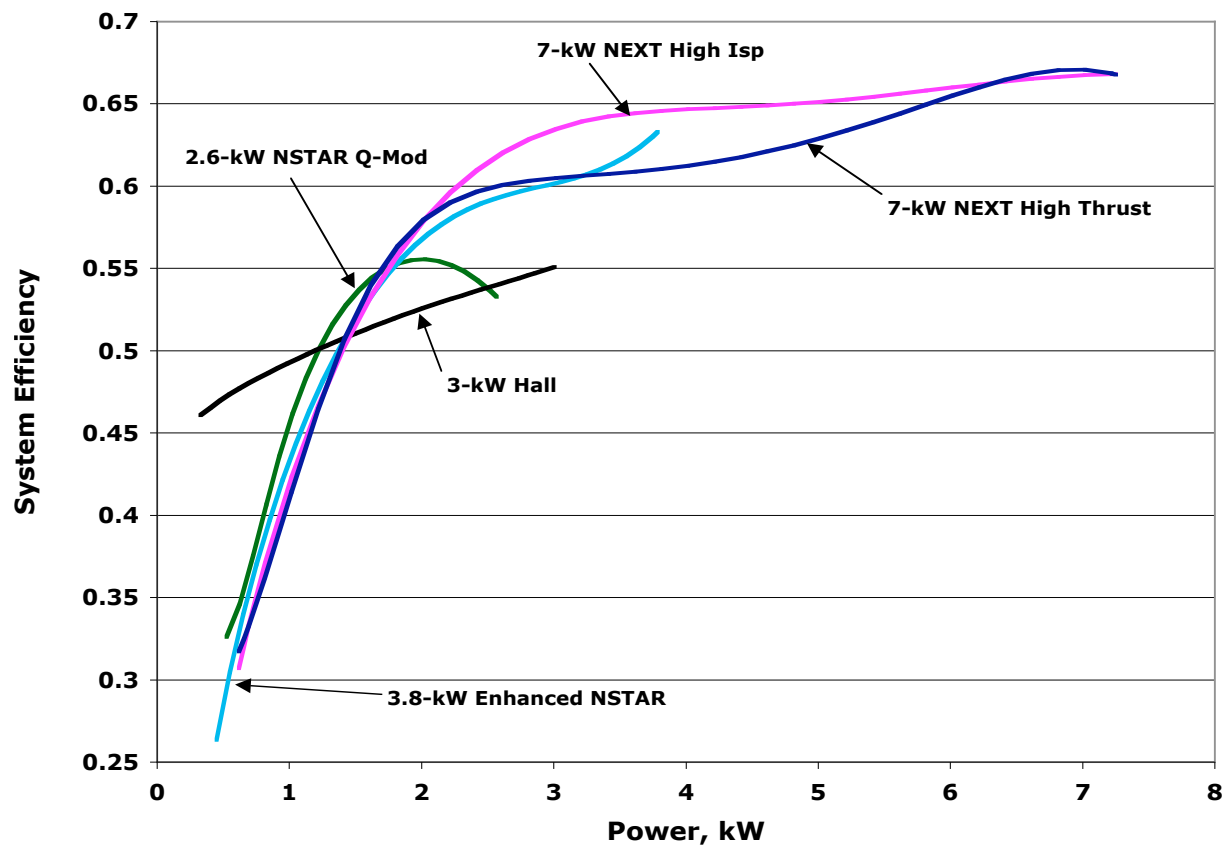

Figure 4. System efficiency vs. power for each SEP technology. 
Table 2 provides the operating range of each thruster and its throughput capability. Its current NASA Technology Readiness Level (TRL) is also shown in Table 2.

As far as this (NF) study is concerned, NEXT is the only thruster considered to have any potential for throttle table modifications. During this study, various NEXT throttle tables were assessed for Discovery and NF class missions to determine which throttle table provided the best overall performance. This progression in throttle tables started with the NEXT baseline throttle table at the start of this study (TT 6) and progressed to TT 9a at the end of the study. The JPOP and CSSR missions assess the performance of NEXT TT 6 and NEXT TT 9a (also referred to as TT 9). Only NEXT TT 9a was assessed for the Titan missions. Essentially, the only thruster modifications considered were increased efficiency and min-max input power variations.

Thruster performance modifications were not considered for the NSTAR and Hall systems. NSTAR is already developed and is scheduled to be the primary propulsion system for the 2006 Discovery-class DAWN mission. Because of its relatively low operating power as compared to NEXT, the 3-kW Hall thruster targets Discovery-class missions and is included in this analysis primarily for completeness. An obvious thruster modification for the 3-kW Hall to be a better candidate thruster for a NF-class mission would be to increase its maximum operating power to a level comparable with NEXT. A different study did consider the relative performance of a higher power variant of the 3-kW Hall thruster and it showed substantial performance benefits. ${ }^{8}$ No such modification was considered for the purpose of this study.

Table 2 Operating range, throughput capability, and current NASA TRL of each SEP technology

\begin{tabular}{lcccc}
\hline \hline \multirow{2}{*}{ Thruster } & \multicolumn{2}{c}{ Power into PPU, } \\
kW & $\begin{array}{c}\text { Maximum } \\
\text { Throughput, kg }\end{array}$ & NASA TRL \\
\cline { 2 - 4 } & Pmin & Pmax & 150 & 9 \\
\hline 2.6-kW NSTAR Q-Mod & 0.525 & 2.567 & 300 & 5 \\
7-kW NEXT & 0.616 & 7.252 & 300 & 4 \\
3.8-kW Enhanced NSTAR & 0.450 & 3.786 & 300 & 4 \\
3-kW Hall & 0.328 & 3.006 & 300 & 4 \\
\hline \hline
\end{tabular}

\section{B. Mass Assumptions}

The mass of each option is technology dependent and is a function of xenon throughput and the number of thrusters and PPUs required for the mission. An overall dry mass is calculated at a subsystem level based on mission requirements and unit level masses provided by technologists. Contingency margin is added in a manner consistent with standard JPL design principals. These principals apply mass margins that vary with unit maturity ranging from $2 \%$ for "build-to-print" hardware to $30 \%$ for new designs. The result is an overall propulsion system margin that varies from $10 \%$ for NSTAR to $30 \%$ for NEXT and the $3-\mathrm{kW}$ Hall. Xenon tank mass is calculated as a fixed fraction of xenon propellant mass to allow direct comparison of propulsion hardware. Three to five percent propellant mass margin is added to account for residuals in the tank and feed system. Additional propellant contingency can be included as appropriate to account for navigation and trajectory errors.

The overall propulsion system masses provided by the technologists are shown in Table 3 . The advanced thrusters have greater throughput capability than NSTAR and typically require fewer thrusters to meet mission requirements. Once the propellant loading is determined from the low-thrust trajectory optimization, the SEP mass (with contingencies) can be calculated and is shown for each mission in section IV. 
Table 3 Major propulsion system masses (kg) as of September 2004

\begin{tabular}{|c|c|c|c|c|}
\hline Componet & $\begin{array}{r}2.6-\mathrm{kW} \\
\text { NSTAR } \\
\text { Q-Mod } \\
\end{array}$ & $\begin{array}{r}3.8-\mathrm{kW} \\
\text { Enhanced } \\
\text { NSTAR } \\
\end{array}$ & $\begin{array}{l}7-\mathrm{kW} \\
\text { NEXT }\end{array}$ & $\begin{array}{r}\text { 3-kW } \\
\text { Hall }\end{array}$ \\
\hline Thruster & 8.20 & 7.39 & 12.40 & 3.60 \\
\hline PPU & 13.90 & 17.60 & 26.00 & 8.40 \\
\hline DCIU & 5.65 & 5.65 & 5.65 & 0.00 \\
\hline Gimbal & 4.64 & 4.64 & 5.00 & 4.64 \\
\hline $\begin{array}{l}\text { Gimbal Drive } \\
\text { Electronics }\end{array}$ & & included & & 2.0 \\
\hline $\begin{array}{l}\text { Feed System } \\
\text { Fixed }\end{array}$ & 8.10 & 8.10 & 2.20 & 4.00 \\
\hline $\begin{array}{l}\text { Feed System } \\
\text { Per Thruster }\end{array}$ & 3.30 & 3.30 & 4.10 & 1.00 \\
\hline $\begin{array}{l}\text { Xenon Tank } \\
\text { Mass Fraction } \\
(\%)\end{array}$ & 4.5 & 4.5 & 4.5 & 4.5 \\
\hline $\begin{array}{l}\text { System } \\
\text { Contingency } \\
(\%)\end{array}$ & 10 & 18 & 30 & 30 \\
\hline
\end{tabular}

The ion systems use redundant Digital Command and Interface Units (DCIUs) to provide command and telemetry interfaces, control the gimbals, and actively regulate xenon flow rates. The Hall system requires no DCIU, but instead incorporates flow control functions into the PPU and gimbal electronics into the spacecraft command system. This distribution of functions is typical for commercial Hall systems and improves the system's mass and cost. The different in architecture is somewhat arbitrary, but partially reflects differences in the operation of Hall and ion thrusters. With ion thrusters, the flow controller regulates separate discharge and neutralizer cathodes and typically closes the loop around temperature and pressure sensors associated with the feed system. This requires the use of redundant pressure sensors and makes the control logic relatively complex. With Hall thrusters, the flow controller regulates only one cathode and closes the loop around the discharge current, making it relatively easy to incorporate the control logic into the PPU. The gimbal control electronics do increase the mass and cost of the spacecraft command distribution system, a penalty that is included in this analysis. It may be possible to improve the mass and cost of ion systems by similarly incorporating flow control functions into the PPU.

\section{Mission Analysis}

\section{A. Jupiter Polar Orbiter with Probes}

\section{Mission Overview}

This mission is cited in the DSSES as the highest priority mission for giant planet research. ${ }^{1}$ The mission's objective is to gain a better understanding of Jupiter's strong magnetic and gravity fields and its deep atmosphere. To meet this objective, the spacecraft is to deliver multiple atmospheric entry probes that can penetrate to the 100 bar pressure level and sample a range a latitudes within 30 degrees of the equator. To avoid the highest-flux parts of the Jovian radiation field, a very low perijove, $<1.1 \mathrm{R}_{\mathrm{J}}$, is necessary. The orbiter is expected to remain in orbit for at least one year.

\section{Transportation Approach}

A launch vehicle that is compatible with the NF cost-cap, the Atlas V 551, is selected to provide the initial $\Delta \mathrm{V}$ to place the spacecraft on hyperbolic trajectory. Long-duration low-thrust is provided by the SEP system for the heliocentric transfer to Jupiter. The trajectory utilizes a Venus gravity assist (VGA) to increase its heliocentric orbital energy, thereby decreasing the launch energy $\left(\mathrm{C}_{3}\right)$ provided by the launch vehicle. After the spacecraft meets the required $\Delta \mathrm{V}$, its thrusters are turned off, the SEP module is jettisoned, and the spacecraft begins its coast phase 
to Jupiter. At Jupiter's sphere-of-influence (JSOI), a SOA chemical system provides the necessary $\Delta \mathrm{V}$ for orbit insertion.

\section{Mission Assumptions}

Two key mission parameters, probe and orbiter mass, were undefined for this study. Two options that are variations of the mission as described above are presented. The first option, assumes that the science objectives might be met without probes. Determining if this option would actually be scientifically viable was not done. The on-board SOA chemical system is responsible for inserting the entire mass at the JSOI. This is called Option A. The second option, Option B, assumes a single probe will be released prior to the orbit insertion maneuver. The mass of this probe was based directly on a published mass of the Galileo probe $(\sim 340 \mathrm{~kg}){ }^{9}{ }^{9}$ However, it must be noted that the Galileo probe was required to penetrate to about $10-20$ bars of atmospheric pressure. ${ }^{10}$ The probes on the JPOP mission are required to withstand pressure at least 5 times greater. One could also think of another scenario that considers the large Galileo-sized probe to be two or three much smaller probes; however, this seems highly questionable due to the deep atmospheric penetration requirements. For both options, the Jupiter post-insertion mass would then be comprised of an orbiter, a radioisotope power source (RPS), and any other necessary mass.

To be consistent with prior JPOP mission analysis, a final orbit with a 30-day period was assumed. ${ }^{11}$ The chemical insertion maneuver is assumed to occur at the perijove altitude of 7,149 km. Thus, the final orbit is a highly eccentric 7,149 km alt x 30-day orbit. Any necessary post-insertion maneuvers were not considered in this study.

The SOA chemical system for the SEP/Chem option is assumed to have a specific impulse of 325 seconds. The propellant is calculated from the rocket equation and the dry stage mass is assumed to be $20 \%$ (i.e. $20 \%$ of the entire chemical system is assumed to be dry mass). This mass fraction is within $1-3 \%$ of the results reported in a similar study in which a SOA chemical system performs the orbit insertion maneuver at Neptune. ${ }^{12}$

The mission analysis work that was done previously showed that a SOA all-chemical transportation option is likely to offer better performance for trip times greater than four years (with multiple gravity assists). ${ }^{11}$ This is shown in Fig. 5. The data shown in this figure would be considered Option A as described above (orbiter only). Clearly, the SOA all-chemical option shows good performance trends for transfer times greater than four years. Two important caveats go along with Fig. 5. The first caveat is that the fidelity of the model has increased since the time that this analysis was performed (incidentally, both models did not assume a fixed mass fraction). The second caveat is that the gravity assist trajectories occur in the $2003-2009$ time frame. As a consequence of this, this chart demonstrates trends only that are likely to occur in a later time frame. Obviously, there would be some shifting of the data due to better modeling and a more feasible time frame.

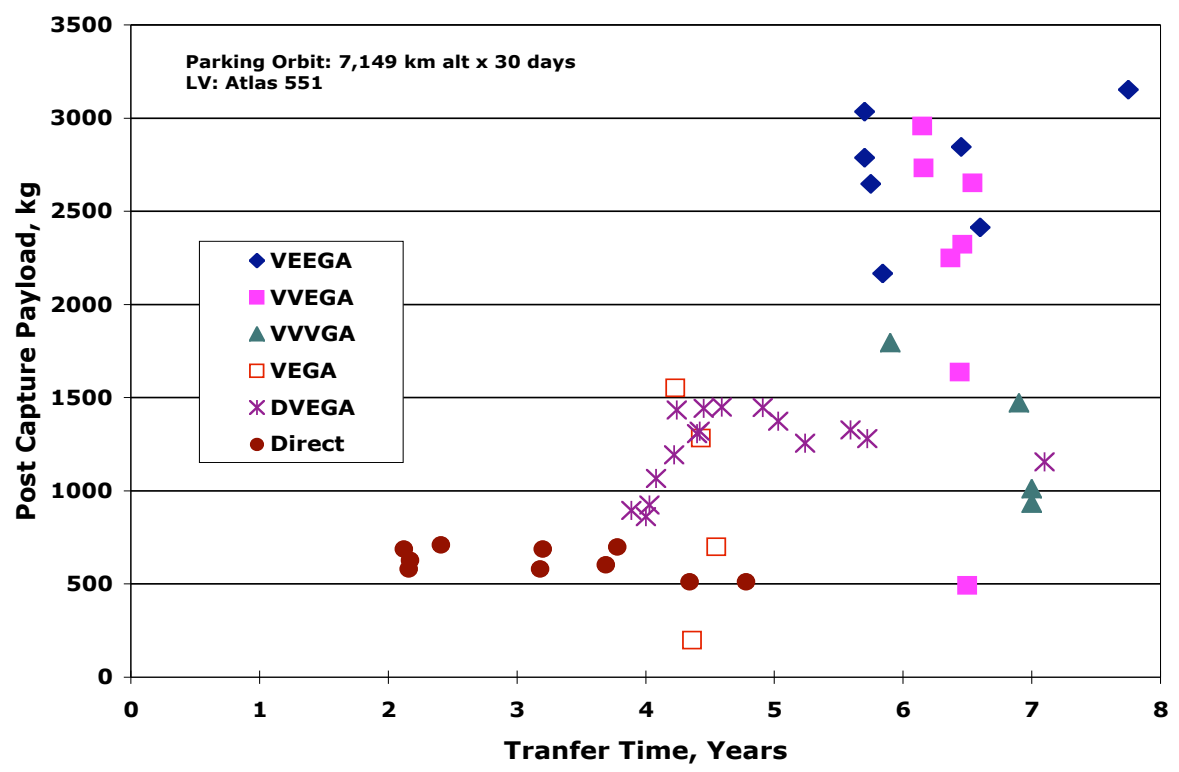

Figure 5. Representative SOA chemical transfers to Jupiter. 
Because of the good performance trends exhibited by the SOA all-chemical transportation option for transfer times greater than four years, a transfer time of less than fours years was selected for the SEP/Chem option. An arrival $V_{\infty}$ sensitivity study was performed to help select the transfer time. This is shown in Fig. 6 for a NEXT propelled spacecraft. The other SEP technologies demonstrate similar performance.

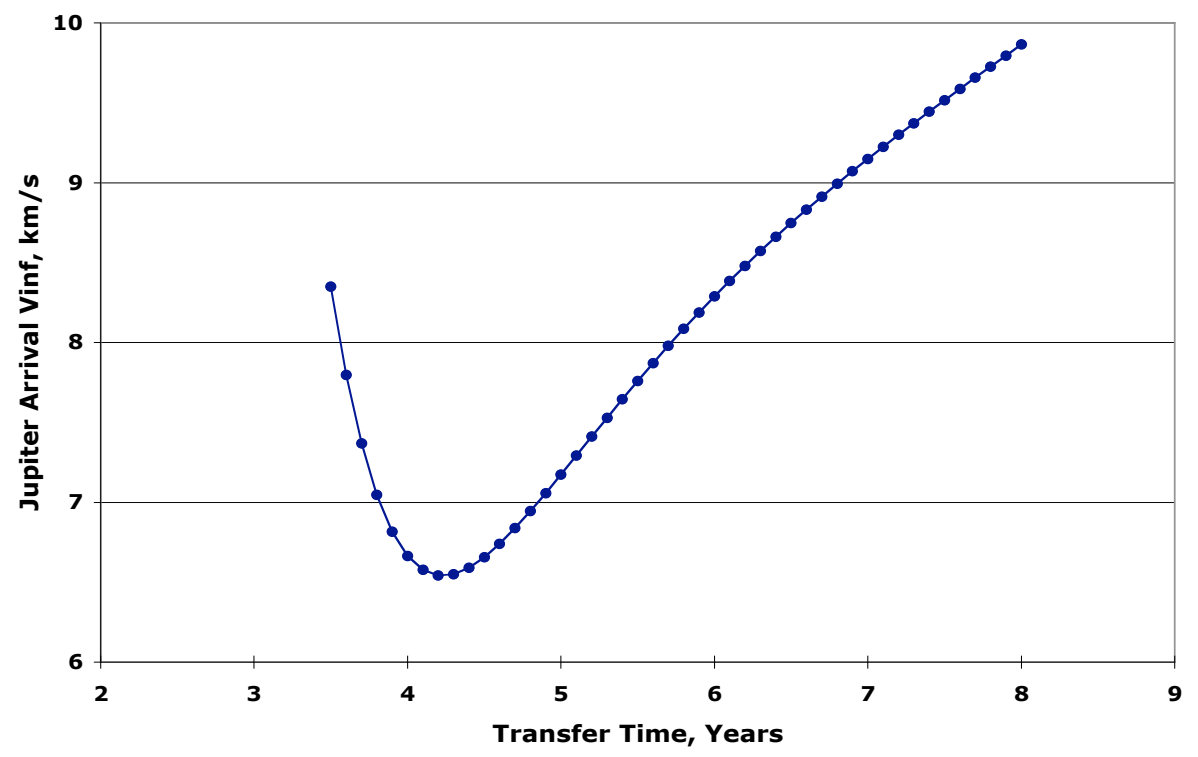

Figure 6. Jupiter arrival $V_{\infty}$ as a function of transfer time.

Although a 4.2-year transfer would result in the best performance for the SEP/Chem. option, due to the minimum (unconstrained) arrival $\mathrm{V}_{\infty}$, prior work showed that the SOA all-chemical option still offered a mass advantage over the SEP/Chem option. ${ }^{11}$ Therefore, a 3.7-year transfer was selected for this study.

A $15-\mathrm{kW}$ BOL array power (referenced at $1 \mathrm{AU}$ ), compatible with the NF cost-cap, was selected as the power source for the electric thrusters. The array power was modeled as $1 / \mathrm{R}^{2}$ with a specific power of $174 \mathrm{~W} / \mathrm{kg}$ $(150 \mathrm{~W} / \mathrm{kg}$ with $16 \%$ structure). An additional $5 \%$ is added to the BOL array power for margin.

As a way to couple the model of the SEP module with the trajectory optimization program, a top-level equation for the launch mass, Eq. (2), was previously developed for input into a refined version of SEPTOP. ${ }^{13}$

$$
M_{\text {Launch }}=\alpha_{\text {power }} \times P+M_{\text {SEP-Fixed }}+M_{\text {payload }} \times\left(1+k_{\text {structure }}\right)+M_{\text {propellant }} \times\left(1+k_{\text {tankage }}\right)
$$

This refinement enables a simplified model of the system masses to be input into SEPTOP via the coefficients in Eq. (2).

Eq. (3) states these variables in terms of the SEPTOP variable names.

$$
m_{0}=\operatorname{alfa}(1) \times P_{0}+\operatorname{alfa}(2)+\operatorname{alfa}(7) \times(1+a l f a(8))+m_{p} \times(1+k t)
$$

$\alpha_{\text {power, }}, \mathrm{k}_{\text {structure, }}$ and $\mathrm{k}_{\text {tankage }}$ are parameters that model the rate at which their respective systems grow. $\mathrm{M}_{\text {SEP-Fixed }}$ is the fixed mass of the SEP model and includes the masses of the thrusters, PPUs, cabling, structure, and thermal system. This parameter changes only when adding or removing a thruster (or PPU). Table 4 provides the input values for each SEP technology. 
Table 4 SEPTOP input parameters

\begin{tabular}{|c|c|c|c|c|}
\hline $\begin{array}{l}\text { Spacecraft Assumptions } \\
\text { [SEPTOP Inputs] }\end{array}$ & $\begin{array}{r}2.6-\mathrm{kW} \\
\text { NSTAR Q-Mod } \\
\end{array}$ & 7-kW NEXT & $\begin{array}{r}3.8-\mathrm{kW} \\
\text { Enhanced } \\
\text { NSTAR } \\
\end{array}$ & 3-kW Hall \\
\hline $\begin{array}{l}\text { \# Thrusters/PPUs } \\
\text { (includes spare) }\end{array}$ & 5 & 3 & 4 & 4 \\
\hline $\begin{array}{l}\text { Fixed mass (Dry SEP } \\
\text { Stage less power \& } \\
\text { tanks) }[\text { alfa(2)], kg }\end{array}$ & 470 & 508 & 462 & 370 \\
\hline Payload [alfa(7)], kg & \multicolumn{4}{|c|}{$800-1200 \mathrm{~kg}$} \\
\hline $\begin{array}{l}\text { Payload Structure } \\
\text { Fraction [alfa(8)] }\end{array}$ & 0.085 & 0.085 & 0.085 & 0.085 \\
\hline $\begin{array}{l}\text { Tankage (includes } \\
\text { structure \& residuals) } \\
{[\mathrm{kt}]}\end{array}$ & 0.143 & 0.153 & 0.147 & 0.175 \\
\hline $\begin{array}{l}\text { Power System Specific } \\
\text { Mass [alfa(1)], kg/kW }\end{array}$ & 9.7 & 9.7 & 9.7 & 9.9 \\
\hline
\end{tabular}

An additional SEPTOP refinement includes a modified model of the propulsion duty cycle. Typically, a 90-95\% propulsion duty cycle is simulated in the trajectory to account for very short coast periods for navigation and trajectory updates. This duty cycle reduces the available thrust and mass flow rate of the thruster. The modification that was made decoupled the thrust and mass flow rate duty cycle by adding $5 \%$ back to the mass flow rate duty cycle. This $5 \%$ of additional propellant is unavailable for thrust and simulates navigation and trajectory modeling errors and propellant feed system leakage that takes place throughout the entire thrusting portion of the trajectory.

Simulating the trajectory in this manner effects how the propellant contingency mass is book kept. Instead of adding an $8-10 \%$ propellant contingency factor, which is typical for these types of simulations, to the total mass of the deterministic propellant (to account for leaks, restarts, filling error, residuals, etc.) only a 3-5\% propellant contingency factor is added to the mass of the deterministic propellant; the other $5 \%$ is assessed by SEPTOP as described above. The rest of the pertinent modeling assumptions are listed below.

- Mission Assumptions:

Jupiter epoch: 24 July 2009

Venus gravity assist

$5 \% \Delta \mathrm{V}$ contingency for chemical orbit insertion

- Launch Vehicle Assumptions:

Atlas V 551

$10 \%$ launch mass contingency

- SEP Stage Assumptions:

Single thruster operation permitted

Single thruster redundancy

$5 \%$ Xenon propellant contingency for flight errors (assessed by SEPTOP)

$3 \%$ Xenon propellant contingency for reserves (Hall: 5\%)

$90 \%$ propulsion duty cycle ( $90 \%$ thrust $\& 95 \%$ mass flow rate)

$174 \mathrm{~W} / \mathrm{kg}$ solar arrays (Hall: $170 \mathrm{~W} / \mathrm{kg}$ )

$5 \%$ mass added to solar arrays for power margin

$1 / \mathrm{R}^{2}$ array power

$2 \%$ per year array degradation

250 Watts supplied for housekeeping activities

Xenon tank mass fraction: $4.5 \%$

Power and Thermal Structure: $16 \%$

Stage Cabling (not PPU): $6 \%$ of power mass

Tankage Mass Fraction includes structure ( $26 \%$ dry) and Xenon propellant contingency for reserves

Spacecraft Adapter: $42 \mathrm{~kg}$ 
NSTAR Q-Mod:

$10 \%$ propulsion system mass contingency for NSTAR Q-Mod (Table 3)

$30 \%$ mass contingency for all other systems

Enhanced NSTAR:

$18 \%$ propulsion system mass contingency for Enhanced NSTAR (Table 3)

$30 \%$ mass contingency for all other systems

NEXT \& Hall:

$30 \%$ dry mass contingency for all systems

\section{JPOP Mission Results}

For each option, the number of operational thrusters selected delivers the largest mass for the chosen transfer time and BOL array power, with one exception. Substantial mass gains can be achieved with additional 3-kW Hall thrusters. ${ }^{8}$ A $3+1$ configuration is chosen because it results in sufficient payload capability relative to the other SEP technologies. These results are shown Fig. 7 and 8. From these two figures, one can see that largest variation between SEP technologies is roughly $200 \mathrm{~kg}$, and that the $3-\mathrm{kW}$ Hall thruster delivers the largest mass.

The NEXT systems offer relatively good performance; both deliver more mass than either NSTAR system with fewer thrusters and are still competitive with the 3-kW Hall. The new baseline NEXT (TT 9a) delivers $16 \mathrm{~kg}$ more mass than the old NEXT baseline (TT 6).

When comparing SEP/Chem (Fig. 7) and SOA all-chemical trends (Fig. 5), one sees that the SOA all-chemical option compares favorably; the utilization of SEP offers shows no real potential for a performance advantage for the near 4 year transfer time.

Detailed mission performance results are shown in Tables 5 and 6 for Option A and B, respectively. A representative trajectory is shown in Fig. 9.

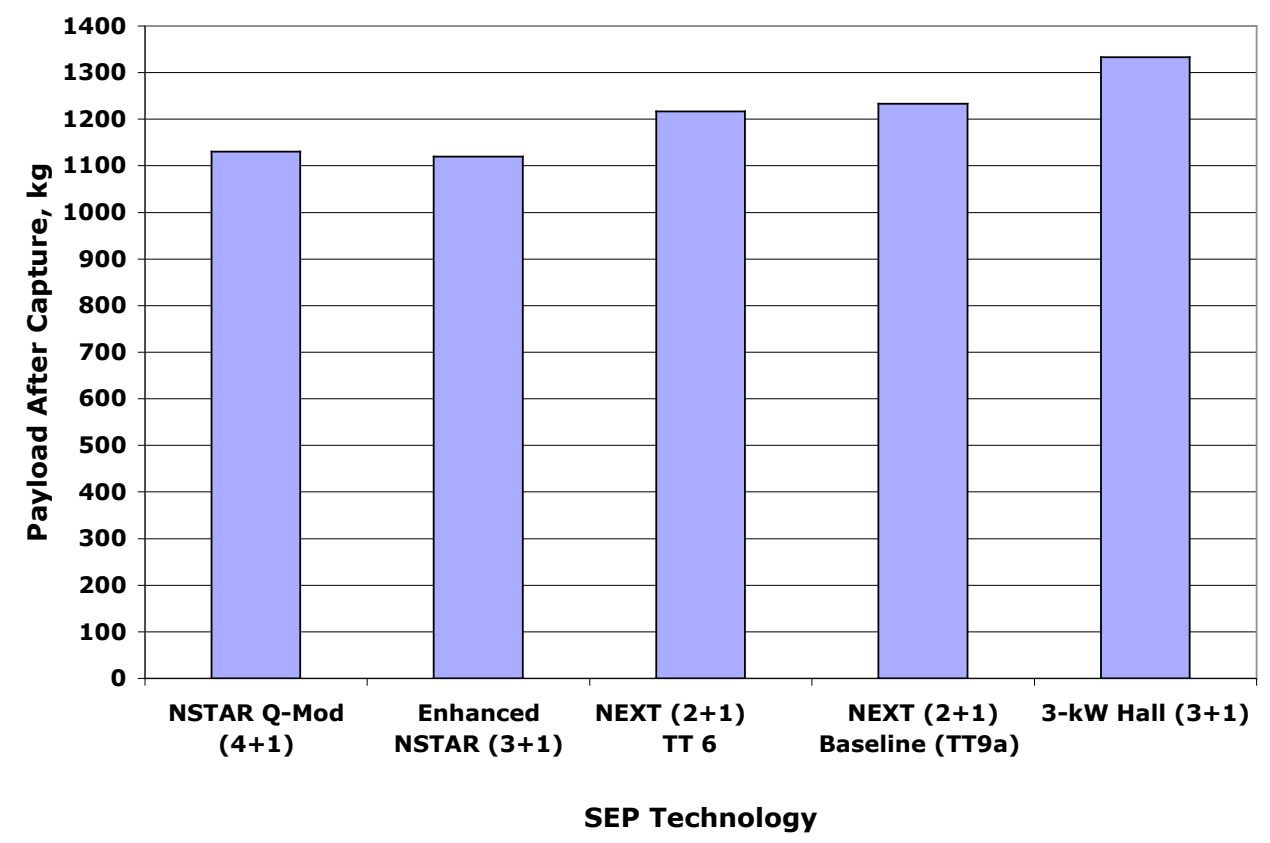

Figure 7. SEP technology performance comparison for a 3.7 year trip time (Option A - Orbiter only). 


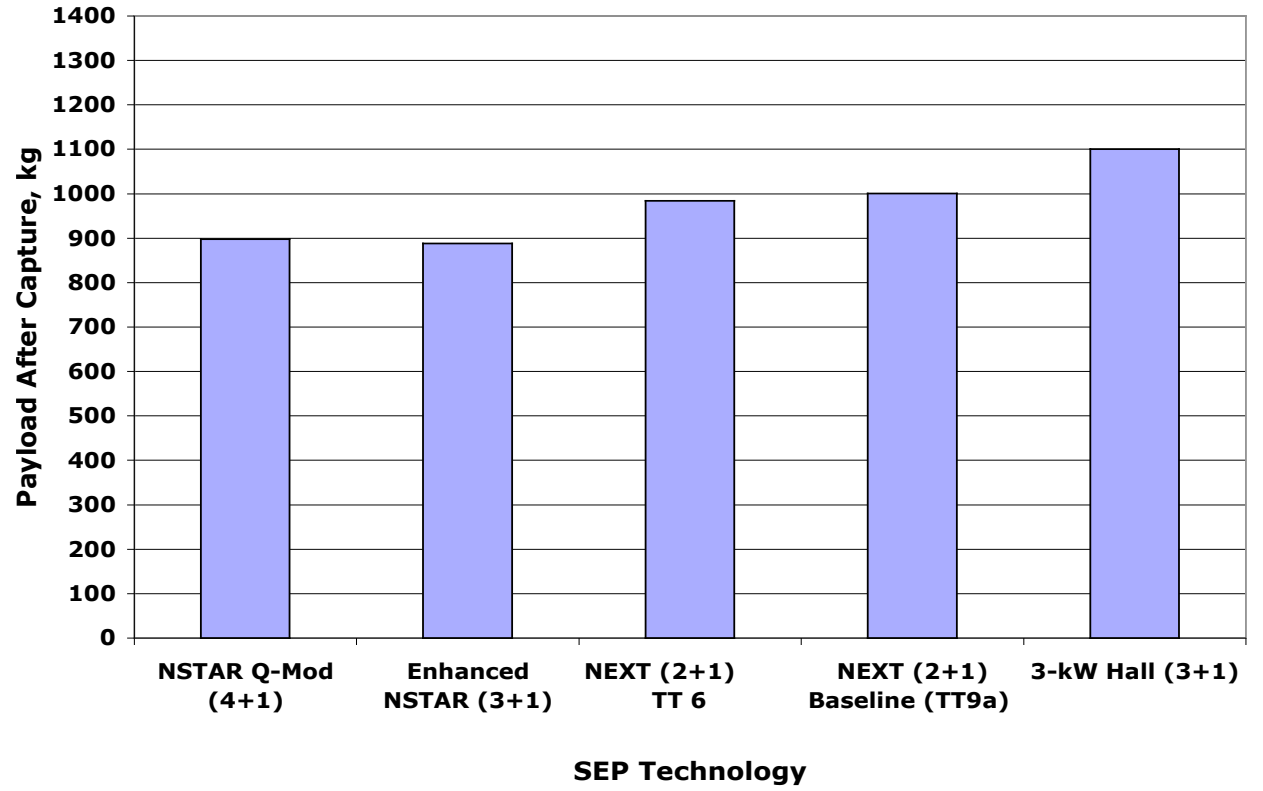

Figure 8. SEP technology performance comparison for a 3.7 year trip time (Option B - 1 large probe \& orbiter).

Table 5 Detailed summary of results for JPOP mission (Option A - Orbiter only)

\begin{tabular}{|c|c|c|c|c|c|}
\hline JPOP Mission Results Summary & NSTAR Q-Mod (4+1) & Enhanced NSTAR $(3+1)$ & $\begin{array}{l}\text { NEXT }(2+1) \\
\text { TT } 6 \\
\end{array}$ & $\begin{array}{c}\text { NEXT (2+1) } \\
\text { Baseline (TT9a) }\end{array}$ & 3-kW Hall $(3+1)$ \\
\hline Throttling Profile & --- & --- & High Thrust (TT 6) & High Thrust (TT 9a) & --- \\
\hline Operating Thrusters & 4 & 3 & 2 & 2 & 3 \\
\hline Redunant Thrusters & 1 & 1 & 1 & 1 & 1 \\
\hline Total Thrusters & 5 & 4 & 3 & 3 & 4 \\
\hline Launch Vehicle & Atlas V 551 & Atlas V 551 & Atlas V 551 & Atlas V 551 & Atlas V 551 \\
\hline Launch Vehicle Contingency & $10 \%$ & $10 \%$ & $10 \%$ & $10 \%$ & $10 \%$ \\
\hline Power 1 AU BOL (kW) & 15 & 15 & 15 & 15 & 15 \\
\hline C3 $\left(\mathrm{km}^{2} / \mathrm{s}^{2}\right)$ & 35.3 & 37.7 & 32.5 & 32.2 & 27.8 \\
\hline Earth Departure Date & 14-Jun-2009 & 12-Jun-2009 & 13-Jun-2009 & 13-Jun-2009 & 20-Jun-2009 \\
\hline VGA Flyby Date & 18-Mar-2011 & 18 -Mar-2011 & 18 -Mar-2011 & 18 -Mar-2011 & 16-Mar-2011 \\
\hline Jupiter Arrival Date & 24-Feb-2013 & 23-Feb-2013 & 24-Feb-2013 & 24-Feb-2013 & 3-Mar-2013 \\
\hline Injected Mass (kg) & 2,994 & 2,861 & 3,163 & 3,179 & 3,454 \\
\hline Dry SEP Module Mass ( $w /$ contingencies) $(\mathrm{kg})$ & 830 & 809 & 882 & 883 & 808 \\
\hline $\begin{array}{l}\text { Xenon Propellant Throughput (includes } 5 \% \\
\text { additional Xe assessed by SEPTOP) (kg) }\end{array}$ & 515 & 418 & 506 & 497 & 709 \\
\hline Xenon Propellant Contingency & $3 \%$ & $3 \%$ & $3 \%$ & $3 \%$ & $5 \%$ \\
\hline Total EP Propellant $(\mathrm{kg})$ & 530 & 431 & 521 & 512 & 744 \\
\hline Mass @ JSOI (kg) & 1649 & 1634 & 1775 & 1798 & 1937 \\
\hline Total Chemical $\Delta \mathrm{V}(\mathrm{m} / \mathrm{s})$ & 922 & 925 & 923 & 923 & 915 \\
\hline Arrival Vinf $(\mathrm{km} / \mathrm{s})$ & 7.37 & 7.38 & 7.37 & 7.37 & 7.31 \\
\hline 30-Day Capture Orbit $\Delta V(\mathrm{~m} / \mathrm{s})$ & 879 & 881 & 879 & 879 & 871 \\
\hline$\Delta \mathrm{V}$ margin \& g-loss & $5 \%$ & $5 \%$ & $5 \%$ & $5 \%$ & $5 \%$ \\
\hline Chemical System Wet Mass (kg) & 518 & 515 & 558 & 565 & 604 \\
\hline Chemical System Propellant $(\mathrm{kg})$ & 414 & 412 & 446 & 452 & 483 \\
\hline Chemical System Dry Mass (kg) & 104 & 103 & 112 & 113 & 121 \\
\hline Estimated Payload After Capture (kg) & 1131 & 1120 & 1217 & 1233 & 1333 \\
\hline $\mathrm{EP} \Delta \mathrm{V}(\mathrm{km} / \mathrm{s})$ & 5.346 & 5.225 & 5.547 & 5.574 & 5.258 \\
\hline Transfer Time (yrs) & 3.7 & 3.7 & 3.7 & 3.7 & 3.7 \\
\hline
\end{tabular}


Table 6 Detailed summary of results for JPOP mission (Option B - 1 large probe \& orbiter)

\begin{tabular}{|c|c|c|c|c|c|}
\hline JPOP Mission Results Summary & NSTAR Q-Mod $(4+1)$ & Enhanced NSTAR $(3+1)$ & $\begin{array}{l}\text { NEXT }(2+1) \\
\text { TT } 6\end{array}$ & $\begin{array}{c}\text { NEXT (2+1) } \\
\text { Baseline (TT 9a) }\end{array}$ & $3-k W$ Hall $(3+1)$ \\
\hline Throttling Profile & Wothe & -.- & High Thrust & High Thrust (TT 9a) & - -1 \\
\hline Operating Thrusters & 4 & 3 & 2 & 2 & 3 \\
\hline Redunant Thrusters & 1 & 1 & 1 & 1 & 1 \\
\hline $\begin{array}{l}\text { Total Thrusters } \\
\text { Tors }\end{array}$ & 5 & 4 & 3 & 3 & 4 \\
\hline Launch Vehicle & Atlas V 551 & Atlas $\vee 551$ & Atlas V 551 & Atlas V 551 & Atlas $\vee 551$ \\
\hline Launch Vehicle Contingency & $10 \%$ & $10 \%$ & $10 \%$ & $10 \%$ & $10 \%$ \\
\hline Power $1 \mathrm{AU} \mathrm{BOL}(\mathrm{kW})$ & 15 & 15 & 15 & 15 & 15 \\
\hline C3 $\left(\mathrm{km}^{2} / \mathrm{s}^{2}\right)$ & 35.3 & 37.7 & 32.5 & 32.2 & 27.8 \\
\hline Earth Departure Date & 14-Jun-2009 & 12-Jun-2009 & 13-Jun-2009 & 13-Jun-2009 & 20-Jun-2009 \\
\hline VGA Flyby Date & 18-Mar-2011 & 18-Mar-2011 & 18-Mar-2011 & 18-Mar-2011 & 16-Mar-2011 \\
\hline Jupiter Arrival Date & $24-\mathrm{Feb}-2013$ & $23-F e b-2013$ & $24-F e b-2013$ & $24-F e b-2013$ & 3-Mar-2013 \\
\hline Injected Mass (kg) & 2,994 & 2,861 & 3,163 & 3,179 & 3,454 \\
\hline Dry SEP Module Mass (w/contingencies) $(\mathrm{kg})$ & 830 & 809 & 882 & 883 & 808 \\
\hline $\begin{array}{l}\text { Xenon Propellant Throughput (includes } 5 \% \\
\text { additional Xe assessed by SEPTOP) (kg) }\end{array}$ & 515 & 418 & 506 & 497 & 709 \\
\hline $\begin{array}{l}\text { Xenon Propellant Contingency } \\
\text { Total EP Propellant }(\mathrm{kg})\end{array}$ & $\begin{array}{l}3 \% \\
530\end{array}$ & $\begin{array}{l}3 \% \\
431\end{array}$ & $\begin{array}{l}3 \% \\
521\end{array}$ & $\begin{array}{l}3 \% \\
512\end{array}$ & $\begin{array}{l}5 \% \\
744\end{array}$ \\
\hline Mass of 1 Galileo size probe $(\mathrm{kg})$ & & 339 & 339 & 339 & 339 \\
\hline & & & & & \\
\hline Mass @ JSOI (kg) & 1649 & 1634 & 1775 & 1798 & 1937 \\
\hline Pre-Insertion Mass (kg) & 1310 & 1295 & 1436 & 1459 & 1598 \\
\hline Total Chemical $\Delta V(\mathrm{~m} / \mathrm{s})$ & 922 & 925 & 923 & 923 & 915 \\
\hline Arrival Vinf $(\mathrm{km} / \mathrm{s})$ & 7.37 & 7.38 & 7.37 & 7.37 & 7.31 \\
\hline 30-Day Capture Orbit $\Delta \mathrm{V}(\mathrm{m} / \mathrm{s})$ & 879 & 881 & 879 & 879 & 871 \\
\hline$\Delta V$ margin \& g-loss & $5 \%$ & $5 \%$ & $5 \%$ & $5 \%$ & $5 \%$ \\
\hline Chemical System Wet Mass (kg) & 412 & 408 & 451 & 459 & 498 \\
\hline Chemical System Propellant $(\mathrm{kg})$ & 329 & 326 & 361 & 367 & 399 \\
\hline Chemical System Dry Mass (kg) & 82 & 82 & 90 & 92 & 100 \\
\hline Estimated Payload After Capture (kg) & 898 & 888 & 984 & 1001 & 1100 \\
\hline EP $\Delta V(\mathrm{~km} / \mathrm{s})$ & 5.346 & 5.225 & 5.547 & 5.574 & 5.258 \\
\hline Transfer Time (yrs) & 3.7 & 3.7 & 3.7 & 3.7 & 3.7 \\
\hline
\end{tabular}

\section{JPOP Mission Summary}

The applicability of the ISP's SEP technologies has been assessed for a 3.7-year transfer to Jupiter with a BOL array power of $15 \mathrm{~kW}$ when launched on an Atlas V 551. A comparison among each SEP technology showed that NEXT is probably the better thruster technology choice due to such factors as its current TRL and the relatively few thrusters that it requires. The current NEXT baseline (TT 9a), delivers $\sim 1.5 \%$ more mass than the old NEXT baseline (TT 6).

In terms of the overall applicability of SEP for this mission, one must consider the SOA all-chemical performance trends that showed a wide range of mass delivery capability. For SEP to be seriously considered a candidate transportation option for this mission, it must offer a substantial mass gain, trip time reduction, cost savings, or some combination of the three relative to the SOA all-chemical option. This study showed that SEP is not likely to offer a mass advantage or trip time reduction with a single VGA (multiple SEP GAs were not investigated) relative to SOA all-chemical. Additionally, a similar study showed that a SOA all-chemical transportation option is less costly than SEP. ${ }^{3}$

Because the SEP/chem option uses a VGA, and the allchemical option would potentially utilize an Earth gravity assist (EGA), the SEP/chem option would avoid any environmental safety concerns when a RPS is flown. This is the only potential benefit that the SEP/chem option might have when compared to the SOA all-chemical option.

The relatively low $\Delta \mathrm{V}$ required for this mission, both for the heliocentric transfer and the orbit insertion maneuver, tend to make the all-chemical option the most attractive transportation option.

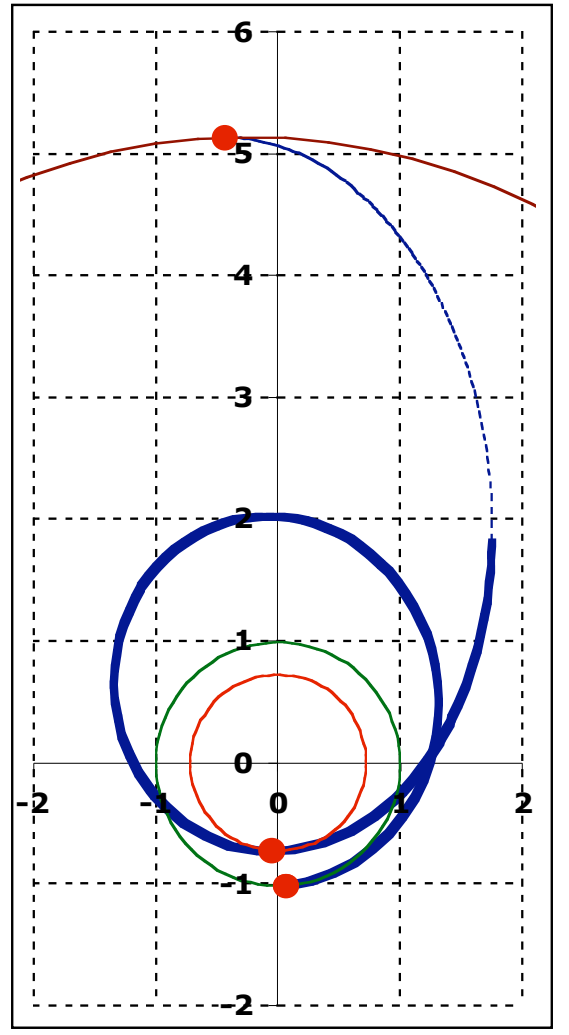

Figure 9. Representative Jupiter trajectory profile (bold curve depicts thrust phase). 


\section{B. Comet Surface Sample Return}

\section{Mission Overview}

This mission is listed as the second highest priority among medium class non-Mars sample return missions in the DSSES (South Pole/Aitkin Basin is first). A more detailed presentation of data for this mission is found in

Reference 14, and thus only a brief outline of the study assumptions and results is provided. The objective of the mission is to rendezvous with a short-period comet, collect a sample from its surface, and then return it to Earth. Temple 1 was selected as the target for this analysis. A summary of Earth and Tempel 1 orbits about the sun are provided in Fig. 10.

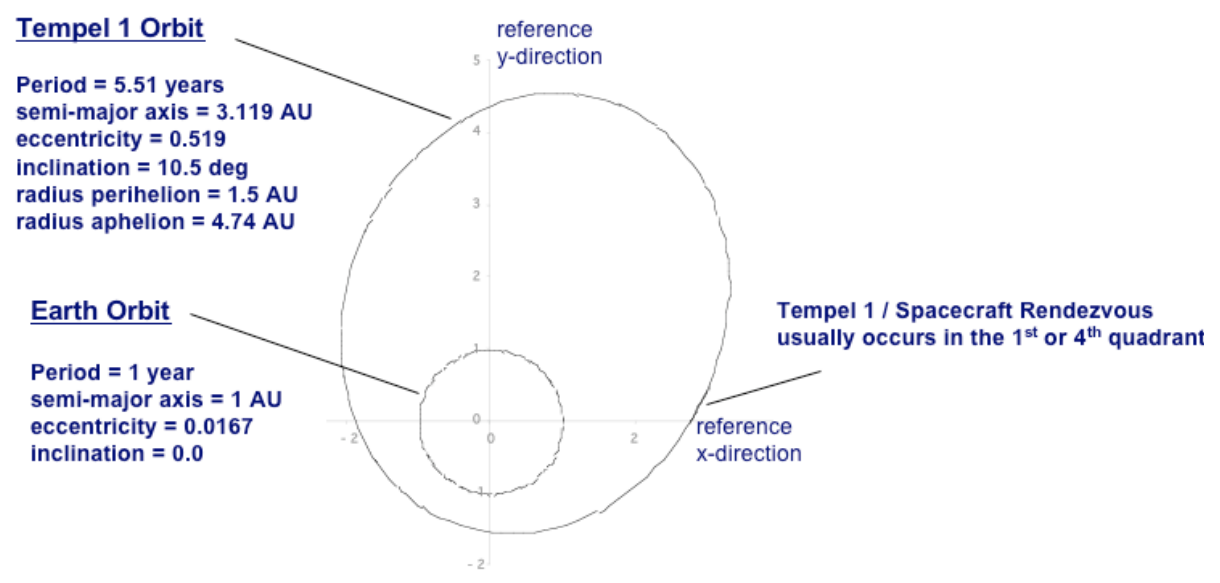

Figure 10. Earth and Temple 1 orbits.

\section{Transportation Approach}

A Delta-IV 4040-12 launch vehicle delivers the SEPS vehicle with payload to an Earth escape trajectory. The performance data for the Delta IV 4040-12 is shown in Fig. 11. ${ }^{15}$ After Earth escape, the electric propulsion system transfers the payload from Earth through a 10.5 degree plane change to a rendezvous with Tempel 1 . After a 60 day stay at the comet that allows for sample gathering and close-up science observation, the electric propulsion system provides the required propulsion to return the comet sample to Earth via a direct entry.

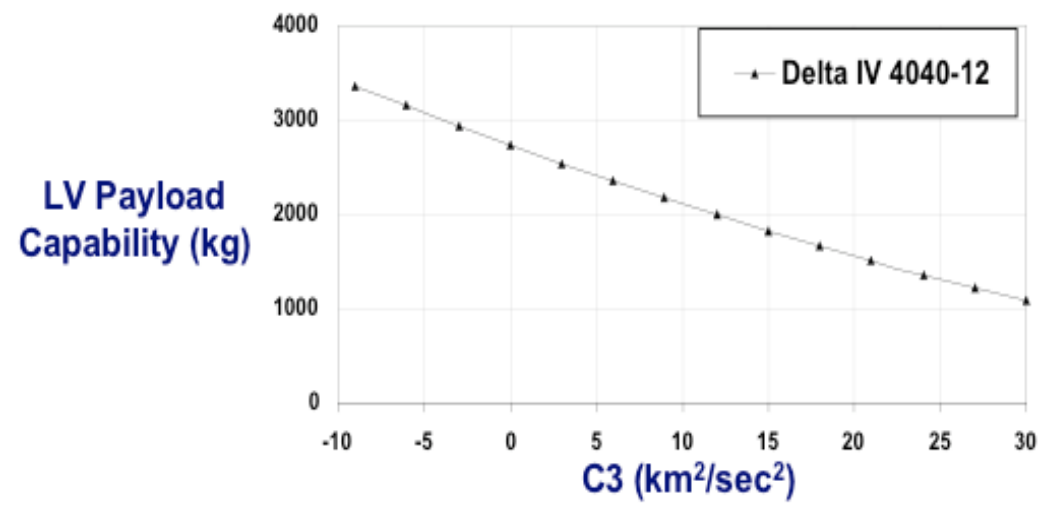

Figure 11. Launch vehicle performance model. 


\section{Mission Assumptions}

The launch date is in the year 2008, and the stay time at Temple 1 is 60 days. A fraction of the total payload, a 50 $\mathrm{kg}$ part of the sample retrieval system, is assumed to remain at the comet after the sample is stowed on the spacecraft.

Preliminary analysis demonstrated that a baseline power of $12 \mathrm{~kW}$ was sufficient for this mission. For all cases investigated, additional power was added for radiation degradation and contingency. The power system assumptions are summarized in Table 7.

Table 7 CSSR solar array assumptions

\begin{tabular}{|l|l|}
\hline Solar Array Power & $\begin{array}{l}12 \mathrm{~kW}, \text { High Performance } \\
\text { Silicon, alpha }=150 \mathrm{~W} / \mathrm{kg}\end{array}$ \\
\hline Housekeeping Power & $250 \mathrm{~W}$ \\
\hline Cell Degradation & $2 \%$ per year \\
\hline Contingency & $\begin{array}{l}5 \% \text { of baseline array to } \\
\mathrm{BOL}\end{array}$ \\
\hline
\end{tabular}

All four SEP technologies were assessed. Those thrusters are listed in Table 8, and include the SOA thruster, NSTAR Qmod, planned for NASA's Dawn mission spacecraft. Note that for the NSTAR Qmod, Enhanced NSTAR, and Low Power (LP) Hall, there are two cases each of thruster number variation. For each thruster case investigated, a $90 \%$ propulsion system duty cycle was assumed. Also note that in all cases investigated in this study, it was assumed that there is always one spare thruster to meet mission reliability requirements in the event a thruster malfunction.

Table 8 Evaluated SEP technologies

\begin{tabular}{|c|c|c|c|c|c|}
\hline Thruster & $\begin{array}{l}\text { NSTAR } \\
\text { Qmod }\end{array}$ & $\begin{array}{l}\text { Enhanced } \\
\text { NSTAR }\end{array}$ & $\begin{array}{l}\text { Low Power } \\
\text { Hall }\end{array}$ & NEXT 6 & NEXT 9 \\
\hline $\begin{array}{l}\text { Cases } \\
\text { Investigated }\end{array}$ & $\begin{array}{l}4 \text { engines + } 1 \\
\text { spare } \\
5 \text { engines + } 1 \\
\text { spare }\end{array}$ & $\begin{array}{l}3 \text { engines }+1 \\
\text { spare } \\
4 \text { engines }+1 \\
\text { spare }\end{array}$ & $\begin{array}{l}4 \text { engines + } 1 \\
\text { spare } \\
5 \text { engines + } 1 \\
\text { spare }\end{array}$ & $\begin{array}{l}2 \text { engines }+1 \\
\text { spare }\end{array}$ & $\begin{array}{l}2 \text { engines }+1 \\
\text { spare }\end{array}$ \\
\hline $\begin{array}{l}\text { Engine Power } \\
\text { Specifications }\end{array}$ & $\begin{array}{l}\text { PPU Power Max } \\
=2.567 \mathrm{~kW} \\
\text { PPU Power Min = } \\
0.525 \mathrm{~kW}\end{array}$ & $\begin{array}{l}\text { PPU Power Max = } \\
3.786 \mathrm{~kW} \\
\text { PPU Power Min = } \\
0.450 \mathrm{~kW}\end{array}$ & $\begin{array}{l}\text { PPU Power Max = } \\
3.006 \mathrm{~kW} \\
\text { PPU Power Min = } \\
0.328 \mathrm{~kW}\end{array}$ & $\begin{array}{l}\text { PPU Power Max = } \\
7.445 \mathrm{~kW} \\
\text { PPU Power Min = } \\
1.225 \mathrm{~kW}\end{array}$ & $\begin{array}{l}\text { PPU Power Max = } \\
7.252 \mathrm{~kW} \\
\text { PPU Power Min = } \\
0.616 \mathrm{~kW}\end{array}$ \\
\hline
\end{tabular}

\section{Mission Results}

Fig. 12 shows a trajectory comparison of three of the thruster cases previously mentioned. It can be seen from this figure that the NSTAR Qmod, with a minimum power of $0.58 \mathrm{~kW}$, is able to thrust beyond 4 AU. The old NEXT baseline (TT 6), with a higher minimum power of $1.23 \mathrm{~kW}$, is unable to perform this high AU thrusting. The current NEXT baseline (TT 9), with a lower minimum power level of $0.62 \mathrm{~kW}$, is able to perform high AU thrusting much like the NSTAR Qmod thruster. Note that each of the three trajectories shown in Fig. 12 optimized to about an 8.1 year total transfer time.

For all cases, the entry velocity at Earth was unconstrained to enable maximum mass capability. Typically, the entry velocities $(125 \mathrm{~km}$ alt.) were $\sim 15 \mathrm{~km} / \mathrm{s}$. For comparison, the STARDUST mission has an expected entry velocity less than $13 \mathrm{~km} / \mathrm{s}^{16}$ Assessing the impact of an entry velocity constraint was not done in this study. 


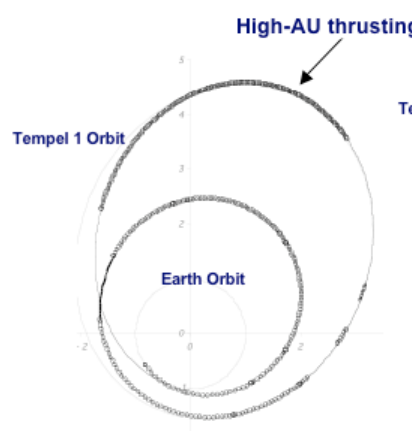

NSTAR Qmod

$P \max =2.57$

$P \min =0.58$

4+1 engines

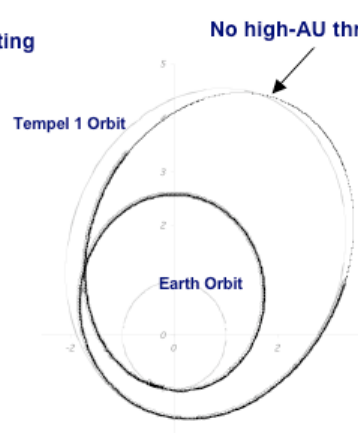

NEXT 6

$P \max =7.45$

$P \min =1.23$

2+1 engines

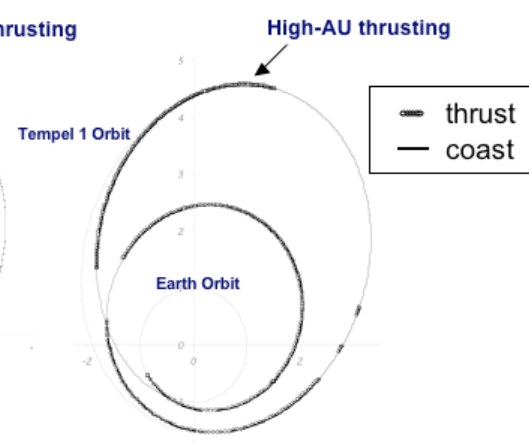

NEXT 9

$P \max =7.23$

$\mathrm{Pmin}=0.62$

2+1 engines

Figure 12. Comparison of mission trajectories.

A payload comparison for each of these thrusters, in addition to the low power Hall and the Enhanced NSTAR thrusters, can be seen in Fig. 13. It is clear that the reduced ability of the old NEXT baseline (TT 6) to operate at high AU limits its mass delivery capability relative to the current NEXT baseline (TT 9), as well as relative to the other thruster cases. The difference in delivered payload for NEXT 9 is over $\sim 150 \mathrm{~kg}$ more payload than NEXT 6. Note that the low power Hall and the NSTAR Enhanced thrusters have relatively low minimum power levels as well.

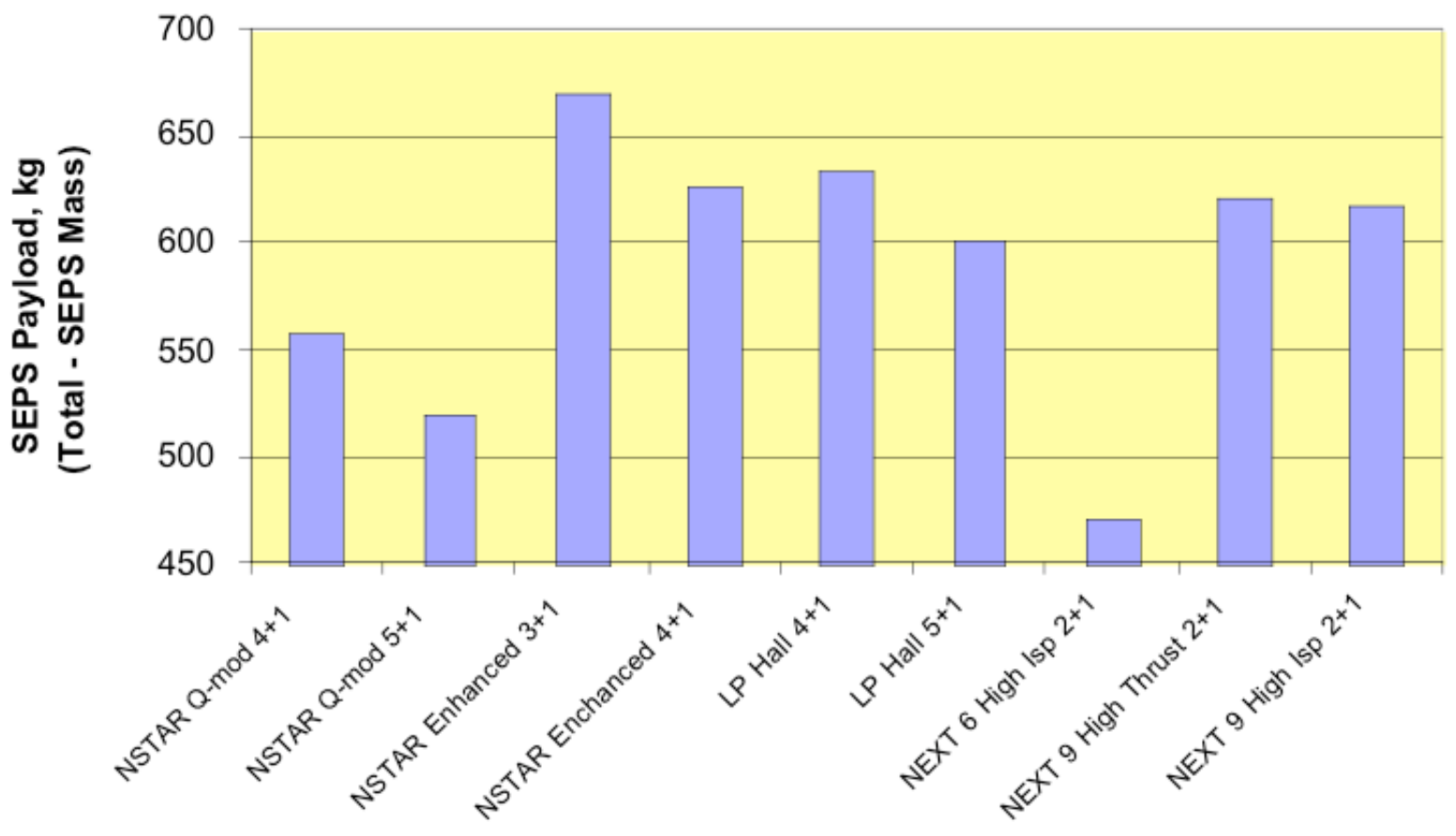

Figure 13. SEPS payload comparison for an 8.1-yr transfer. 
Fig. 13 shows that as the number of operational thrusters is reduced, payload increases for all thrusters except for NEXT (two operational thrusters provided just over the total number of thrusters required to use the total $12 \mathrm{~kW}$ of power, and thus no other combination of thrusters was investigated for NEXT). It is uncertain if still fewer operational thrusters (except for NEXT) would result in a payload increase — only the thruster variations shown were considered.

\section{Mission Summary}

This analysis showed that the lower minimum operating power for the current NEXT baseline (TT 9), relative to the old NEXT baseline (TT 6), enabled a $\sim 30 \%$ payload increase due to its ability to thrust at higher AU. Although the Enhanced NSTAR delivers $\sim 50 \mathrm{~kg}$ more payload than NEXT, it requires an additional thruster; therefore, NEXT seems to be the most applicable thruster technology for this mission. Future analysis will need to assess the impact of meeting an entry velocity constraint, and determine if more mass can be delivered with even fewer thrusters for Enhanced NSTAR and LP Hall.

\section{Titan}

1. Study Overview

Although Titan has not been previously identified as a New Frontiers destination in either the Decadal Survey or in New Frontiers program announcements of opportunity, it is a target of interest to the planetary science community and may become a candidate for a future cost-capped mission opportunity in the New Frontiers cost class. The objective of this study was to determine if a scientifically viable mission to Titan could be conducted within the New Frontiers cost cap using solar electric propulsion (SEP). For this analysis, we assumed the cost cap was $\$ 725$ million in FY04 dollars. While the Jupiter Polar Orbiter and Comet Surface Sample Return studies focused on performance comparisons, this study examines the overall feasibility of the mission concepts. The NEXT subsystem was selected as a representative EP system and two Titan missions were defined and costed by JPL's Advanced Projects Design Team, ("Team X"), which uses a real time collaborative engineering team to quickly develop new mission and spacecraft concepts and designs. Since the objective was to determine feasibility, the mission concepts use minimal "science floor" payloads, relatively aggressive design assumptions and incorporate no descope options. The resulting mission concepts and cost estimates should be considered as a general indication of feasibility rather than as optimized point designs.

Previous work emphasized the use of SEP with chemical propulsion or aerocapture to deliver both an orbiter and an in-situ probe to Titan. ${ }^{17,18}$ This study considers two lower cost mission options that use a combination of SEP and chemical propulsion to deliver either an orbiter or an in-situ probe to Titan. Both missions are class A/B requiring redundancy for critical systems with 30\% mass and power margins maintained for all elements of the spacecraft except the SEP system. A 30\% dry mass margin, $10 \%$ propellant mass margin, and $5 \%$ power margin are maintained for the SEP system.

\section{Titan Orbiter Spacecraft Description}

The primary mission objective for the Titan orbiter is to deliver a $68 \mathrm{~kg}$ science instrument payload to a $1200 \mathrm{~km}$ circular orbit around Titan. The notional payload includes a high-resolution camera capable of mapping the clouds and surface of Titan at a nominal resolution of $30 \mathrm{~m}$ and a millimeter wave spectrometer for atmospheric measurements. As described previously, the payload is notional and should be considered as a straw man "science floor" payload. The trajectory selected for this mission utilizes SEP in combination with an Earth gravity assist to provide an 8 year flight time to Saturn with a launch in 2011. The gravity assist opportunity recurs annually and the trajectory is shown Fig 14. The spacecraft is launched directly to Earth escape with a $C_{3}$ of $11.6 \mathrm{~km}^{2} / \mathrm{s}^{2}$. The SEP module is jettisoned as the spacecraft moves away from the sun (beyond 3 Astronomical Units) and orbit insertion at Saturn is conducted using a bipropellant propulsion system. A Saturn Orbit Insertion (SOI) maneuver performed at 1.3 Saturn radii puts the spacecraft into a 160 day orbit. It is followed by a periapsis raise maneuver that puts the spacecraft into a Titan rendezvous orbit. The spacecraft is then injected into an elliptical orbit at Titan, followed by a 9 month aerobraking campaign in Titan's atmosphere to lower apoapsis and reach the final science orbit. Even with aerobraking, the required $\Delta \mathrm{V}$ for SOI and TOI is substantial, over $2800 \mathrm{~m} / \mathrm{s}$. In addition, aerobraking at Titan carries substantial risk because it has never been done before and because the Earth-Titan light travel time is of the same order as the orbital period at the end of the aerobraking phase. The selected science orbit is quite low, and may not be acceptable due to atmospheric drag. Moving to a higher science orbit will degrade effective resolution of the imager. After insertion, a nominal 3 year surface mapping science mission is conducted by the orbiter. 


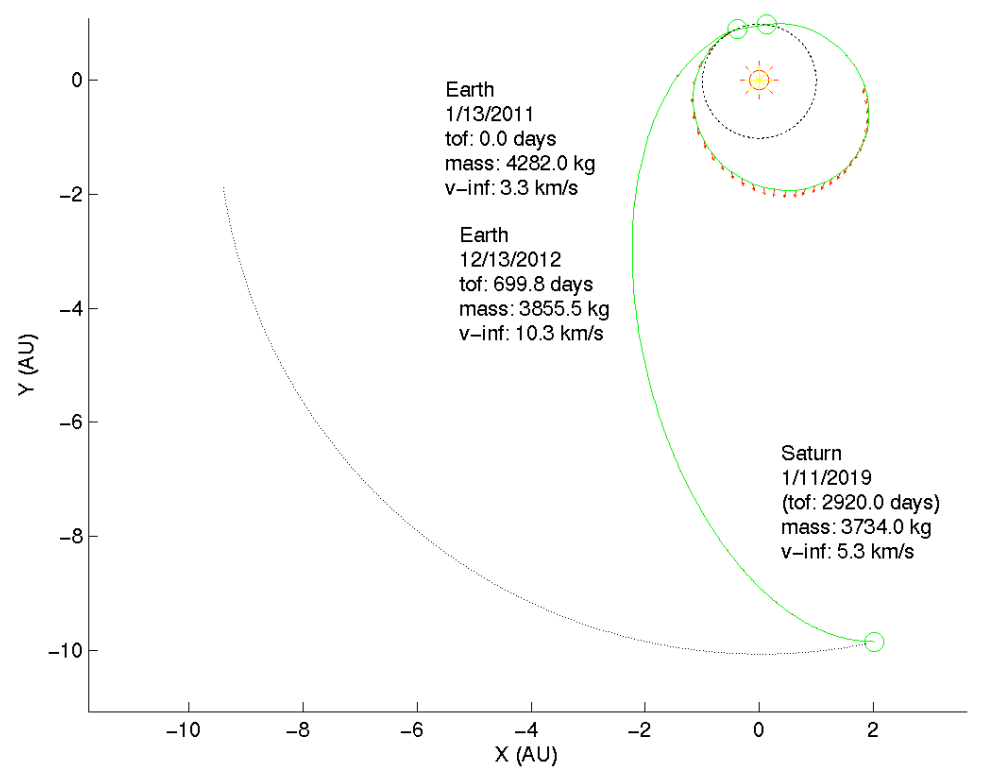

Figure 14. Titan Orbiter trajectory overview.

The spacecraft consists of two main modules, an orbiter and a SEP module. The orbiter contains the science instruments, attitude control sensors and avionics, communications system, non-solar power system, and a large bipropellant chemical propulsion system. Three multi-mission radioisotope thermoelectric generators (MMRTG's) provide power for the payload and for an $\mathrm{X} / \mathrm{Ka}$ band communication system that uses a $4.5 \mathrm{~m}$ diameter parabolic antenna to communicate with Earth from Titan orbit at a peak rates of $114 \mathrm{kbps}$ in X band and $62 \mathrm{kbps}$ in Ka band. The science return is effectively limited by the data rate, which is in turn limited by the power available on the orbiter.

The SEP module contains the electric propulsion system, solar arrays, and thermal control system required to operate three NEXT thrusters simultaneously. It contains no communications or attitude control system; these functions are provided by the orbiter. The spacecraft is launched in an Atlas V 531 launch vehicle as shown in Fig. 15 and the SEP module supports the orbiter during launch. After spacecraft separation, four solar arrays are deployed as shown in Fig 16. The arrays use 30\% efficient advanced multi-junction cells that generate $20 \mathrm{~kW}$ of power at BOL at a distance of $1 \mathrm{AU}$ from the sun. A single redundant thruster and power supply are included in the module. The mass of the orbiter and SEP module are shown in Table 9. 
Table 9 Titan Orbiter/Lander Mission Summary

\begin{tabular}{|c|c|c|}
\hline Option & SEP-Chem Orbiter & SEP Direct Lander \\
\hline $\begin{array}{l}\text { Payload Mass }(\mathbf{k g}) \\
\text { Instruments } \\
\text { In-Situ Probe }\end{array}$ & $\begin{array}{c}68 \\
\text { None } \\
\end{array}$ & $\begin{array}{l}\text { None } \\
715 \\
\end{array}$ \\
\hline $\begin{array}{l}\text { Spacecraft Mass (kg) (1) } \\
\text { Orbiter (dry) } \\
\text { Orbiter Propellant }\end{array}$ & $\begin{array}{c}943 \\
1259\end{array}$ & \\
\hline $\begin{array}{l}\text { SEP Stage (dry) } \\
\text { SEP Stage Propellant, Xenon }\end{array}$ & $\begin{array}{l}1105 \\
616\end{array}$ & $\begin{array}{c}1290 \\
277\end{array}$ \\
\hline $\begin{array}{l}\text { SEP Stage Propellant, Chemical } \\
\text { Total Launch Mass ( } \mathbf{k g})\end{array}$ & $\begin{array}{c}0 \\
3923 \\
\end{array}$ & $\begin{array}{c}41 \\
\mathbf{1 6 0 8} \\
\end{array}$ \\
\hline LV & Atlas V 531 & Delta 4040-12 \\
\hline $\mathrm{C} 3\left(\mathrm{~km}^{2} / \mathrm{s}^{2}\right)$ & 10.8 & 17.2 \\
\hline Trajectory Type & SEP $w / E G A$ & SEP w/EGA \\
\hline Transit Time & 8.1 yrs & 5.9 yrs \\
\hline Science Mission Duration & 3 years & 1 month \\
\hline Titan Arrival Maneuvers & $\begin{array}{c}\text { Chemical SOI/TOI + } \\
\text { Aerobraking } \\
\end{array}$ & Direct Entry \\
\hline Titan Entry Velocity & & $6.4 \mathrm{~km} / \mathrm{s}$ \\
\hline Power, SEP Stage (1 AU, BOL, kW) & $20 \mathrm{~kW}$ & $6 \mathrm{~kW}$ \\
\hline $\begin{array}{l}\text { Electric Propulsion } \\
\text { Type of Thruster } \\
\text { Simultaneous Operating Thrusters (Max) } \\
\text { Total Thrusters (Primary + Redundant) }\end{array}$ & $\begin{array}{l}\text { NEXT } \\
3 \\
3+1\end{array}$ & $\begin{array}{l}\text { NEXT } \\
1 \\
1+1\end{array}$ \\
\hline $\begin{array}{l}\text { Total Data Collected } \\
\text { ROM Cost, \$ FY04 }\end{array}$ & $\begin{array}{l}>2 \text { Tbits } \\
\mathbf{\$ 9 2 5} \mathbf{M}\end{array}$ & $\begin{array}{l}\text { 4-50 Gbits (3) } \\
\mathbf{\$ 7 2 2} \mathbf{M}(\mathbf{2}) \\
\end{array}$ \\
\hline
\end{tabular}

All masses include $30 \%$ dry mass contingency

(1) Assumes a fixed cost of $\$ 178 \mathrm{M}$ for the probe

(2) Assumes mission duration from 1-6 months, data rate $4.5 \mathrm{kbps}$, 8 to 16 hrs communication per day

Team X's standard costing methodology was used to generate an estimate for the total life cycle cost of the project in FY 2004 dollars. Team X uses a quasi-grass roots costing in which most costs are estimated by engineers using parametric models at a subsystem level. The ROM cost shown in Table 9 includes the cost of management, project systems engineering, mission assurance, science, operations, and launch vehicle. It also assumes a $30 \%$ cost reserve in phases A through D and $15 \%$ cost reserve in phase E. The final result, $\$ 925 \mathrm{M}$, is well over the New Frontiers cost cap. Given the relatively aggressive assumptions made in the study (a science floor payload, low science orbit, use of aerobraking), it is unlikely that a scientifically viable Titan Orbiter mission can be conducted for less than $\$ 725 \mathrm{M}$ using SEP with chemical propulsion for Titan capture. 


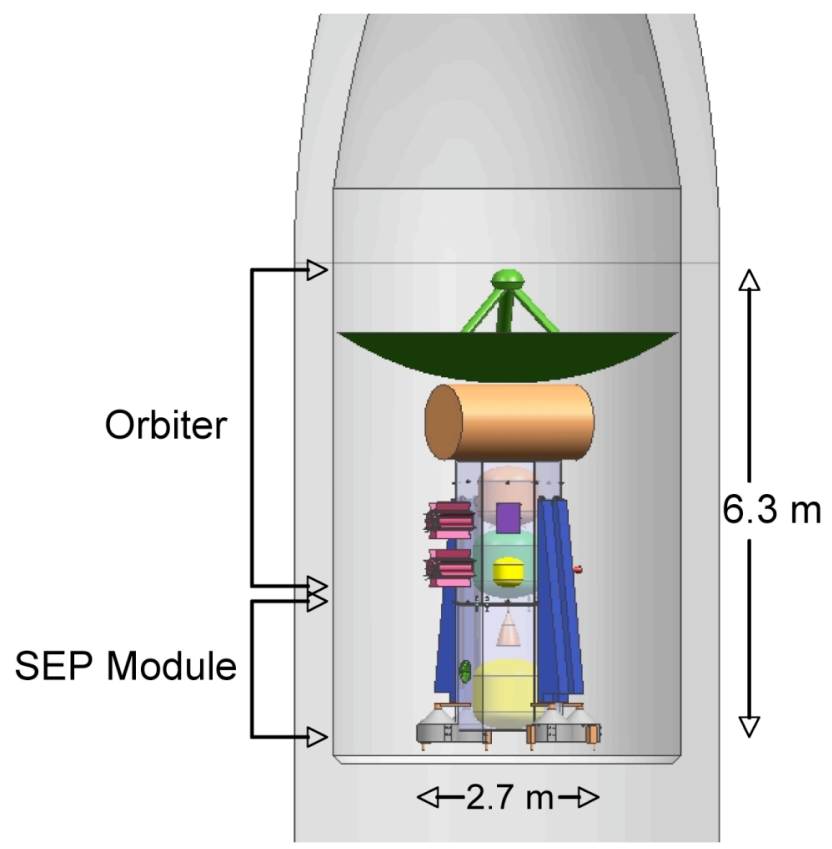

Figure 15. Titan Orbiter in stowed configuration.

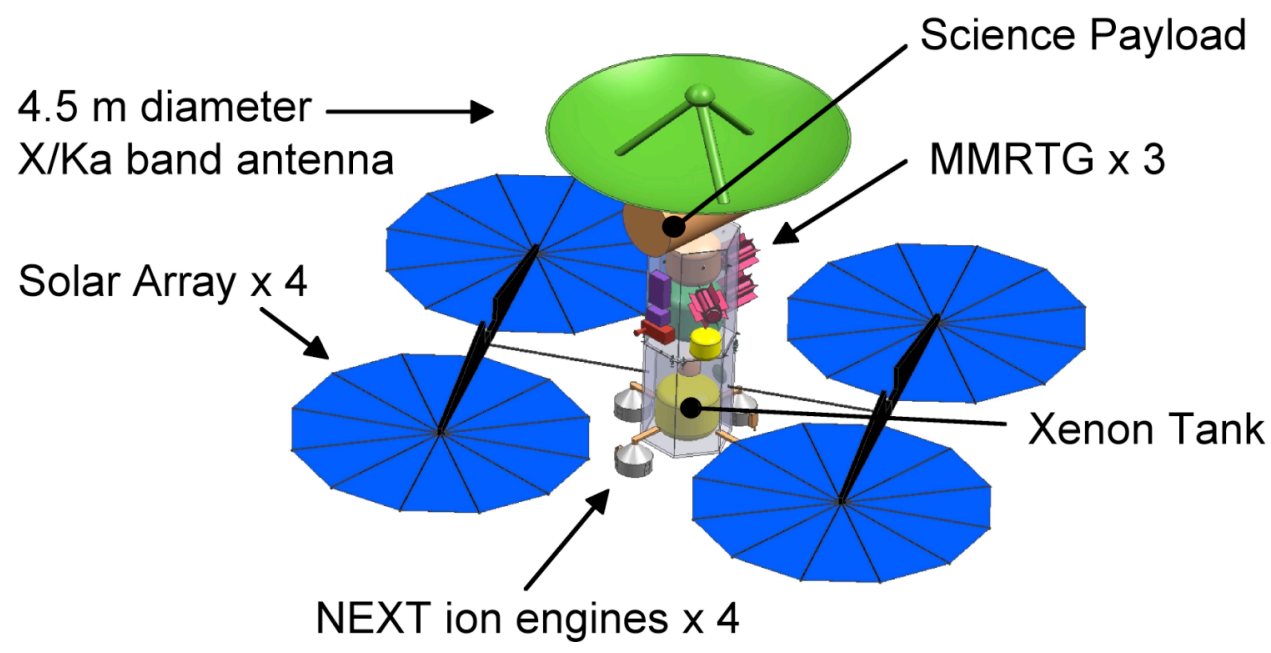

Figure 16. SEP - Titan Orbiter in deployed configuration.

\section{Titan Direct Lander Spacecraft Description}

The primary mission objective for the Titan lander is to deliver a $715 \mathrm{~kg}$ in-situ probe to the surface of Titan. The mass allocation includes the scientific payload and surface mobility systems as well as the entry, descent, and landing system (aeroshell, parachute, etc). The in-situ probe was treated as a "black box" and no detailed design was conducted of the lander. However, the mass allocated for the lander is twice the mass of the Huygens probe and is large enough to accommodate existing notional concepts for a mobile Titan "aerobot". Table 10 shows the mass of the black box Titan in-situ payload compared with existing, planned, and proposed interplanetary in-situ probes. 
Table 10 Mass of Titan In-Situ Probe compared to existing/planned/proposed entry systems

\begin{tabular}{|l|c|}
\hline & $\begin{array}{c}\text { Approximate } \\
\text { Entry Mass (kg) }\end{array}$ \\
\hline Huygens & 350 \\
Mars Pathfinder & 585 \\
Notional Titan Aerobot & 19 \\
Mars Phoenix & 600 \\
Black Box "New Frontiers" Probe & 610 \\
Mars Exploration Rover (MER) & $\mathbf{7 1 5}$ \\
\hline
\end{tabular}

The trajectory selected for this mission utilizes SEP in combination with an Earth gravity assist to provide a 5.9 year flight time to Titan with a launch in 2011. The gravity assist opportunity recurs annually and the trajectory is shown in Fig. 17. The spacecraft is launched directly to Earth escape with a $C_{3}$ of $10.8 \mathrm{~km}^{2} / \mathrm{s}^{2}$. When the spacecraft reaches Titan, the SEP module is jettisoned and the lander conducts a direct entry to Titan with an entry speed of 6.4 $\mathrm{km} / \mathrm{s}$. The lander mission requires much less propellant than the orbiter, resulting in a much lighter spacecraft and a much smaller (and less expensive) SEP system. The spacecraft is also launched on a smaller launch vehicle, the Delta 4040-12, rather than on the larger Atlas 531. After landing, it is assumed that a one month science mission in conducted on the surface. This assumes a "science floor" mission, which could be extended with a relatively small impact to the overall cost of the program.

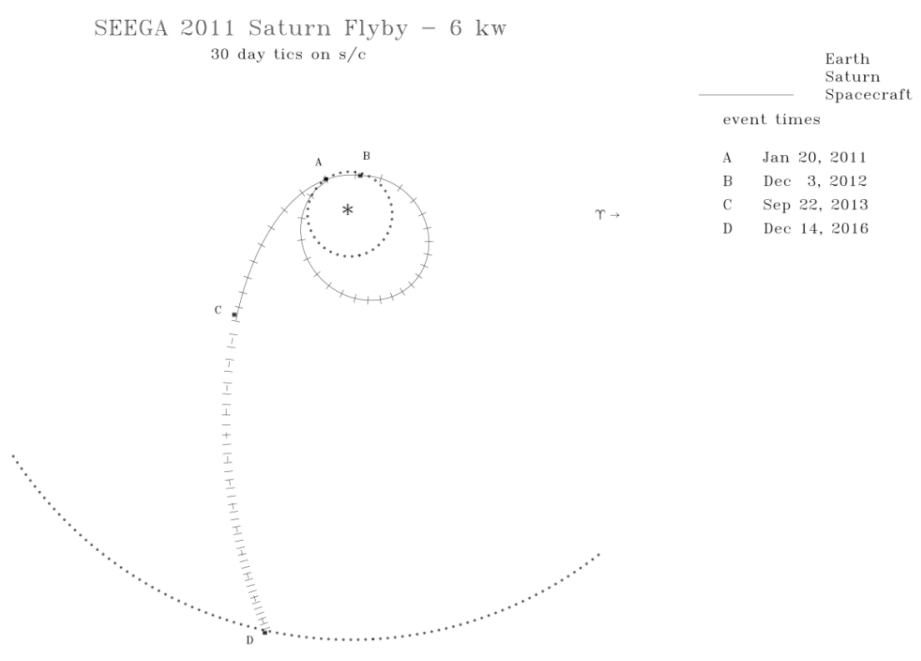

seegadelta40406kw.bin
Apr 14, 2005 10:13:20

Figure 17. Titan Lander trajectory overview.

The spacecraft consists of two main modules, a SEP stage and an in-situ probe. The probe's power and thermal control systems operate independently of the SEP stage during launch and cruise, and the probe provides communications with Earth through all phases of the mission. The probe also communicates directly with Earth after 
landing and the science return is likely to be limited by the achievable data rate. Previous work has estimated that data rates of approximately 4.5 kilobits per second may be achievable from the surface using a $0.8 \mathrm{~m}$ X-band parabolic antenna. ${ }^{19}$ Depending on the duty cycle, this would provide between 100 and 300 megabits of data per day. Further work is needed to determine if this data rate provides sufficient science to justify the mission.

The SEP module contains an electric propulsion system for primary propulsion, a chemical propulsion system for secondary propulsion, solar arrays, data handling, and thermal control system. After spacecraft separation, two solar arrays are deployed with a power generation capability of $6 \mathrm{~kW}$ at BOL, $1 \mathrm{AU}$. A single NEXT (high thrust throttling profile) provides primary propulsion. A single redundant thruster and power supply are also included in the module. The mass of the SEP module and in-situ probe is shown in Table 9.

Team X's standard costing methodology was used to cost the SEP module, science, and operations costs. Because no detailed design was conducted for the probe, it was necessary to assume a cost for the probe hardware, software, integration, and testing. A cost of $\$ 178 \mathrm{M}$ was assumed for the Titan entry system, including instruments, resulting in a total program cost of approximately $\$ 725 \mathrm{M}$ (FY 04).

\section{Titan Summary}

The lander only option is much less expensive than the orbiter because the SEP system is smaller, the mission duration is shorter, the launch vehicle is smaller, and the carrier spacecraft is simpler. There is, however, considerable uncertainty in the cost, as it is not known how much it would cost to construct a Titan in-situ probe. In addition, the duration of the science mission would probably need to be extended to have a scientifically viable mission. It should be noted that the general mission architecture is not sensitive to mass. Because launch vehicle is a low-end medium class vehicle, larger payloads can be accommodated with moderate cost increases by switching to a slightly larger launch vehicle. Several hundred kilograms of additional payload could be accommodated on an Atlas 551 vehicle.

Based on these results, we conclude that a SEP direct lander mission to Titan may be possible at a cost close to the New Frontiers cost cap. Further work is needed to better define the design and verify that the mission is scientifically viable. In particular, better definition is needed of the science mission and of the cost of an in-situ probe designed to operate at Titan.

\section{Conclusions}

In order to meet the two-part objective of this Refocus Study, the ISP's SEP technologies have been assessed for their potential applicability for three candidate New Frontiers class missions, and thruster performance modifications (for NEXT) have been assessed in an effort to increase its applicability. The findings of this study are listed below.

(1) The increased overall efficiency and lower min-max power of NEXT TT 9a enabled a $\sim 2 \%-30 \%$ payload increase for the JPOP and CSSR mission, respectively, relative to NEXT TT 6 . As a consequence of this performance improvement demonstrated by NEXT TT 9a in this study and in the Discovery-class Refocus Study, NEXT TT 9a was adopted as the current NEXT baseline throttle table. ${ }^{2}$ Just like in the Discovery portion of the Refocus Studies, the key modification was lowing the minimum input power from $\sim 1.2 \mathrm{~kW}$ to $\sim 0.6 \mathrm{~kW}$. A comparison of the old NEXT baseline TT 6 and the current NEXT TT 9a is shown in Fig. 18 and 19.

(2) Not all NF-class missions will benefit equally from the NEXT throttle table modifications; the delivered mass increase was much greater for the CSSR mission than JPOP, due to the higher AU thrusting requirement.

(3) Only the current NEXT baseline thruster (TT 9a) was assessed for the Titan mission; however, based on the JPOP mission analysis results, one could infer that the NEXT TT 9a would offer a similar (slight) performance improvement over NEXT TT 6 due to similar thrust-coast (vs. AU) profiles.

(4) SEP is not (likely to be) applicable for the JPOP mission because of the relatively sufficient mass delivery capability of SOA all-chemical. 
(5) For the CSSR mission, NEXT required the fewest thrusters (three total) to deliver sufficient mass relative to the other electric thrusters, and is therefore found to be applicable for this mission.

(6) Only NEXT was assessed for the Titan mission; results showed that a Titan Orbiter mission is not likely to be within the NFclass cost cap, but the Titan Lander concept does show promise. Therefore, NEXT is also applicable for this mission.

A complete mission/technology application matrix is shown in Table 11; the results of the Discovery-class portion of the Refocus Study are also shown.

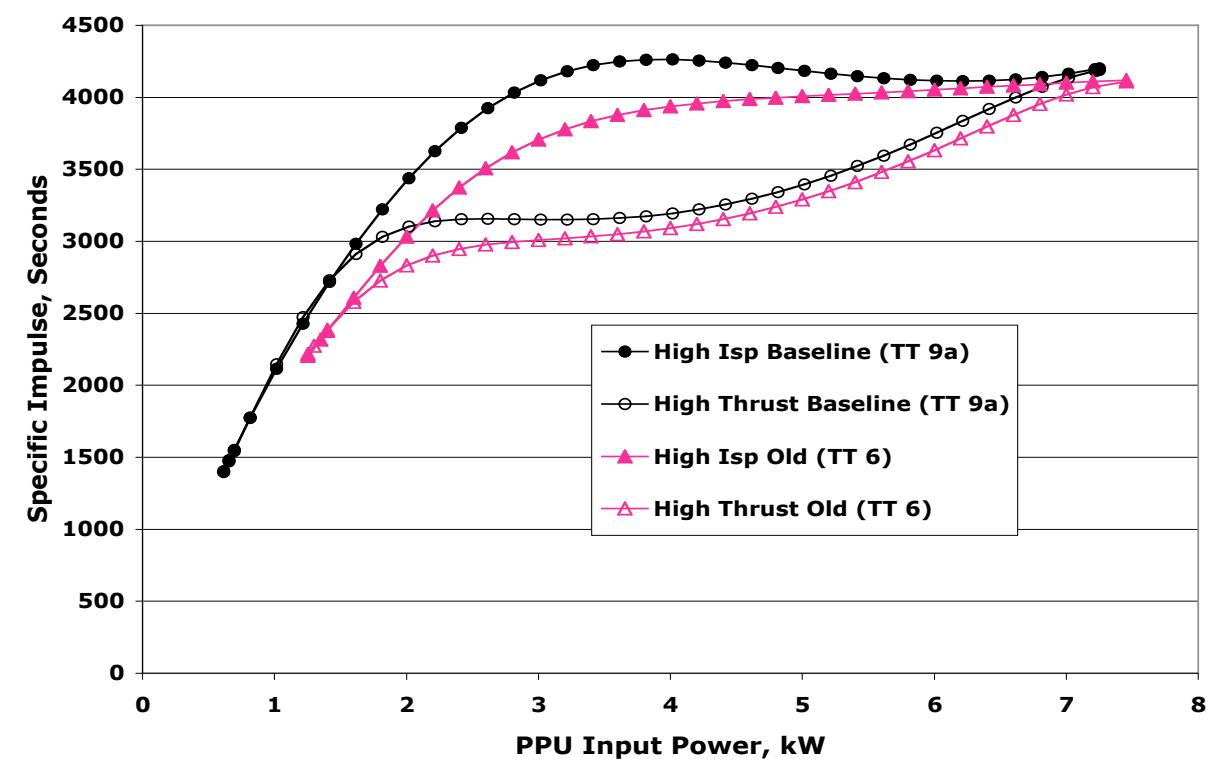

Figure 18. Specific impulse vs. PPU power comparison for NEXT TT 6 and TT 9a.

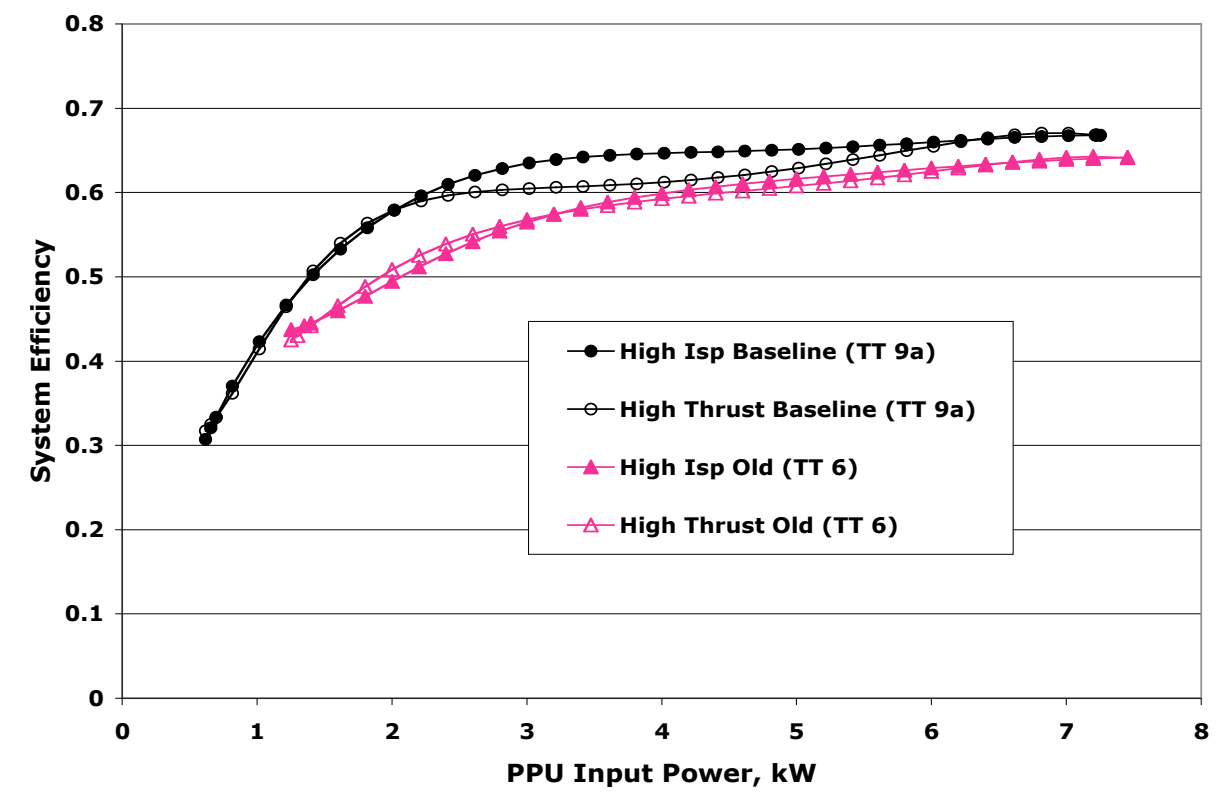

Figure 19. Overall efficiency vs. PPU power comparison for NEXT TT 6 and TT 9a. 
Table 11 SEP application matrix

\begin{tabular}{|c|c|c|c|c|c|c|c|c|}
\hline & \multicolumn{3}{|c|}{ "Discovery" (< 10 kW) } & \multicolumn{3}{|c|}{ "New Frontiers" (< 18 kW) } & \multicolumn{2}{|c|}{ Larger Missions (>20 kW) } \\
\hline & $\begin{array}{c}\text { Vesta- } \\
\text { Ceres RV }\end{array}$ & $\begin{array}{c}\text { Near- } \\
\text { Earth } \\
\text { Asteroid }\end{array}$ & $\begin{array}{c}\text { Comet } \\
\text { RV }\end{array}$ & $\begin{array}{c}\text { Titan } \\
\text { Lander } \\
\text { (Notional) }\end{array}$ & $\begin{array}{l}\text { Comet } \\
\text { Surface } \\
\text { Sample } \\
\text { Return }\end{array}$ & $\begin{array}{l}\text { Jupiter } \\
\text { Polar } \\
\text { Orbiter }\end{array}$ & Titan Explorer & $\begin{array}{l}\text { Neptune } \\
\text { Orbiter }\end{array}$ \\
\hline BOL Array Power & $9 \mathrm{~kW}$ & $6 \mathrm{~kW}$ & $9 \mathrm{~kW}$ & $6 \mathrm{~kW}$ & $15 \mathrm{~kW}$ & $15 \mathrm{~kW}$ & $\sim 30 \mathrm{~kW}$ & $\sim 30 \mathrm{~kW}$ \\
\hline NSTAR, 1 thruster & $\mathrm{X}$ & $\mathrm{X}$ & & & & & ND & ND \\
\hline NSTAR, multi-thruster & & $x$ & $\mathrm{x}$ & $?$ & & & ND & ND \\
\hline Low Power Hall Thruster & $x X$ & $x x$ & $x X$ & $?$ & $(X)$ & & ND & ND \\
\hline Enhanced NSTAR & $\mathrm{X}$ & $\mathrm{X}$ & & $?$ & $(X)$ & & ND & ND \\
\hline NEXT Low Power Update & $\mathrm{x}$ & $\mathrm{x}$ & $\mathrm{x}$ & $x$ & $\mathrm{X}$ & & $x$ & $\mathrm{X}$ \\
\hline $\begin{array}{l}X X=\text { Possibly Cost Enabling } \\
X=\text { Applicable } \\
(X)=\text { Possibly Applicable }\end{array}$ & & $\begin{array}{l}\text { Red }=\text { No } \\
?=\text { Not et } \\
\text { ND }=\text { Not }\end{array}$ & $\begin{array}{l}\text { Applical } \\
\text { luated } \\
\text { esigned }\end{array}$ & for this Ap & lication & & & \\
\hline
\end{tabular}

When looking at Table 11, one must be aware of several issues:

- For the CSSR mission:

- Only one target (Temple 1) was considered;

- LP Hall and Enhanced NSTAR are classified as "possibly applicable" because more than three total thrusters were "required"- -similar mass delivery capability may be possible with fewer thrusters, but this was not investigated;

- For the Titan Lander (Notional) mission:

- Because of the relatively small array $(6 \mathrm{~kW}, \mathrm{BOL} 1 \mathrm{AU})$ it is reasonable to think that other SEP technologies would also be applicable (or, at least, possibly applicable);

- For Earth sample return missions:

- Imposing and meeting an entry velocity constraint (or larger TPS mass requirement) could change the classifications;

- Future mission analyses work could show applicability for a SEP technology/mission different than this study (for example, a particular SEP technology could be more applicable for one target comet than another).

Because of these issues, this SEP technology/mission should not be viewed as static and universal.

\section{References}

${ }^{1}$ http://www.aas.org/ dps/decadal/

${ }^{2}$ Oh, D.,"Evaluation of Solar Electric Propulsion Technologies for Discovery Class Missions," $41^{\text {st }}$ AIAA/ASME/SAE/ASEE Joint Propulsion Conference, AIAA 2005-4270, July 10-13, 2005.

${ }^{3}$ Oh, D., Cupples, M., Belcher, J., Witzberger, K., Fiehler, D., Artis, G. R., "Evaluation of Radioisotope Electric Propulsion for Selected Interplanetary Science Missions," $29^{\text {th }}$ IEPC, Princeton University, October 31 - November 4, 2005 (to be published).

${ }^{4}$ Brophy, J. et al., "Status o f the Dawn Ion Propulsion System," AIAA 2004-3433, 40 ${ }^{\text {th }}$ AIAA/ASME/SAE/ASEE Joint Propulsion Conference, Fort Lauderdale, FL, July 2004.

${ }^{5}$ Patterson, M.J., et al., "NEXT: NASA'S Evolutionary Xenon Thruster Development Status," 39 $9^{\text {th }}$ AIAA/ASME/SAE/ASEE Joint Propulsion Conference, AIAA 2003-4862, July, 2003.

${ }^{6}$ Snyder, J.S. and Brophy, J.R. "Performance Characterization and Vibration Testing of 30-cm Carbon-Carbon Ion Optics," AIAA 2004-3959, 40 ${ }^{\text {th }}$ Joint Propulsion Conference, Fort Lauderdale, FL, July 2004.

${ }^{7}$ Integrated Technology Plan for the Civil Space Program, JCM-7410, March 17, 1991.

${ }^{8}$ Witzberger, K.E., and Manzella, D., "Performance of Solar Electric Powered Deep Space Missions Using Hall Thruster Propulsion," $41^{\text {st }}$ AIAA/ASME/SAE/ASEE Joint Propulsion Conference, AIAA 2005-4268, July 10-13, 2005. 
${ }^{9} \mathrm{http}: / /$ galileo.jpl.nasa.gov/facts.cfm

${ }^{10} \mathrm{http} / / / \mathrm{nssdc} . \mathrm{gsfc}$. nasa.gov/planetary/galileo.html

${ }^{11}$ Oh, D., Benson, S., Witzberger, K., and Cupples, M., "Deep Space Mission Applications for NEXT: NASA's Evolutionary Xenon Thruster," $40^{\text {th }}$ AIAA/ASME/SAE/ASEE Joint Propulsion Conference, AIAA 2004-3806, July 11-14, 2004.

${ }^{12}$ Noca, M. A., and Bailey, R. W., "Mission Trades for Aerocapture at Neptune," $40^{\text {th }}$ AIAA/ASME/SAE/ASEE Joint Propulsion Conference, AIAA 2004-3843, July 11-14, 2004.

${ }^{13}$ Oleson, S., Gefert, L., Benson, S., Patterson, M., Noca, M., Sims, J., "Mission Advantages of NEXT: NASA's Evolutionary Xenon Thruster," $38^{\text {th }}$ AIAA/ASME/SAE/ASEE Joint Propulsion Conference, AIAA 2002-3969, July 7-10, 2002.

${ }^{14}$ Cupples M. L., Woo, B., Coverstone, V. L., "Application of Solar Electric Propulsion to a Comet Surface Sample Return Mission”, 2004 Joint Propulsion Conference, AIAA 2004-3804, July 11-14, 2004.

${ }^{15} \mathrm{http} / / /$ elvperf.ksc.nasa.gove/elvMap/index.html

${ }^{16} \mathrm{http} / / /$ stardust.jpl.nasa.gov/mission/details.html

${ }^{17}$ Noca, M. A., and Bailey, R. W., "Titan Explorer Mission Trades From The Perspective of Aerocapture," $39^{\text {th }}$ AIAA/ASME/SAE/ASEE Joint Propulsion Conference, AIAA 2003-4801, July, 2003.

${ }^{18}$ Advanced Projects Design Team (Team X), Titan Orbiter 2003-10, Report ID \#658, October 7,9,10, 2003.

${ }^{19}$ Hall, J.L., et al., “An Aerobot for Global In Situ Exploration of Titan,” $35^{\text {th }}$ COSPAR Scientific Assembly, Paris, France, July 2004. 


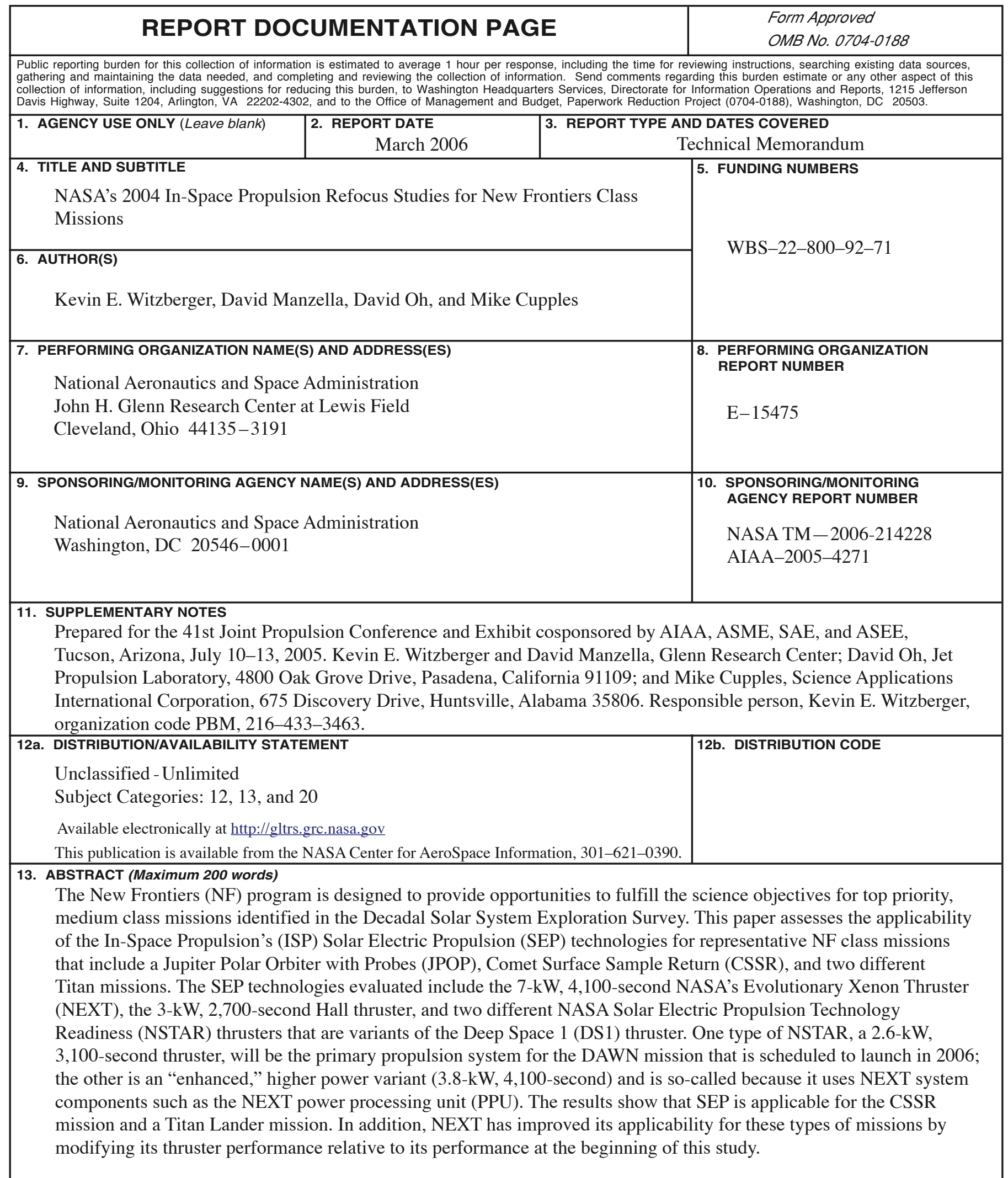

\begin{tabular}{|l|l|l|l}
\hline 14. SUBJECT TERMS & 15. NUMBER OF PAGES
\end{tabular}

Solar electric propulsion

\begin{tabular}{|c|c|c|c|}
\hline $\begin{array}{c}\text { 17. SECURITY CLASSIFICATION } \\
\text { OF REPORT } \\
\text { Unclassified }\end{array}$ & $\begin{array}{c}\text { 18. SECURITY CLASSIFICATION } \\
\text { OF THIS PAGE } \\
\text { Unclassified }\end{array}$ & $\begin{array}{c}\text { 19. SECURITY CLASSIFICATION } \\
\text { OF ABSTRACT } \\
\text { Unclassified }\end{array}$ & 20. LIMITATION OF ABSTRACT \\
\hline
\end{tabular}

NSN 7540-01-280-5500

Standard Form 298 (Rev. 2-89)

Prescribed by ANSI Std. Z39-18 298-102 

